\title{
Assessing the diversity of whiteflies infesting cassava in Brazil
}

\author{
Cesar A.D. Xavier ${ }^{1}$, Angélica Maria Nogueira ${ }^{1}$, Vinicius Henrique Bello ${ }^{2}$, Luís Fernando Maranho Watanabe ${ }^{2}$, \\ Tarsiane Mara Carneiro Barbosa ${ }^{1}$, Miguel Alves Júnior ${ }^{3}$, Leonardo Barbosa ${ }^{4}$, José E.A. Beserra-Júnior ${ }^{5}$, \\ Alessandra Boari ${ }^{6}$, Renata Calegario ${ }^{7}$, Eduardo Silva Gorayeb ${ }^{8}$, Jaime Honorato Júnior ${ }^{9}$, Gabriel Koch ${ }^{7}$, Gaus \\ Silvestre de Andrade Lima ${ }^{10}$, Cristian Lopes ${ }^{4}$, Raquel Neves de Mello ${ }^{11}$, Késsia Pantoja ${ }^{6}$, Fábio Nascimento Silva ${ }^{8}$, \\ Roberto Ramos Sobrinho ${ }^{10}$, Enilton Nascimento Santana ${ }^{12}$, José Wilson Pereira da Silva ${ }^{13}$, Renate Krause-Sakate \\ Corresp., 2 , Francisco M Zerbini ${ }^{\text {Corresp. } 1}$ \\ 1 Dep. de Fitopatologia/BIOAGRO, Universidade Federal de Viçosa, Viçosa, MG, Brazil \\ 2 Dep. de Proteção Vegetal, Universidade Estadual Paulista, Botucatu, SP, Brazil \\ 3 Faculdade de Engenharia Agronômica, Universidade Federal do Pará, Altamira, PA, Brazil \\ 4 Instituto Federal do Sudeste de Minas Gerais, Rio Pomba, MG, Brazil \\ 5 Dep. de Fitotecnia, Universidade Federal do Piauí, Teresina, PI, Brazil \\ 6 Embrapa Amazônia Oriental, Belém, PA, Brazil \\ 7 Dep. de Fitotecnia e Fitossanidade, Universidade Federal do Paraná, Curitiba, PR, Brazil \\ ${ }^{8}$ Centro de Ciências Agroveterinárias, Universidade do Estado de Santa Catarina, Lages, SC, Brazil \\ 9 Centro Multidisciplinar do Campus de Barra, Universidade Federal do Oeste da Bahia, Barra, BA, Brazil \\ 10 Centro de Ciências Agrárias/Fitossanidade, Universidade Federal de Alagoas, Rio Largo, AL, Brazil \\ 11 Embrapa Arroz e Feijão, Santo Antonio de Goiás, GO, Brazil \\ 12 Instituto Capixaba de Pesquisa e Extensão Rural, Linhares, ES, Brazil \\ 13 Faculdade de Engenharia Florestal, Universidade Federal do Pará, Altamira, PA, Brazil \\ Corresponding Authors: Renate Krause-Sakate, Francisco M Zerbini \\ Email address: renate.krause@unesp.br, zerbini@ufv.br
}

Background. The necessity of a competent vector for transmission is a primary ecological factor driving the host range expansion of plant arthropod-borne viruses, with vectors playing an essential role in disease emergence. Cassava begomoviruses severely constrain cassava production in Africa. Curiously, begomoviruses have never been reported in cassava in South America, the center of origin for this crop. It has been hypothesized that the absence of a competent vector in cassava is the reason why begomoviruses have not emerged in South America.

Methods. We performed a country-wide whitefly diversity study in cassava in Brazil. Adults and/or nymphs of whiteflies were collected from sixty-six cassava fields in the main agroecological zones of the country. A total of 1,385 individuals were genotyped based on mitochondrial cytochrome oxidase I sequences.

Results. A high species richness was observed, with five previously described species and two putative new ones. The prevalent species were Tetraleurodes acaciae and Bemisia tuberculata, representing over $75 \%$ of the analyzed individuals. Although we detected, for the first time, the presence of Bemisia tabaci Middle East-Asia Minor 1 (BtMEAM1) colonizing cassava in Brazil, it was not prevalent. The species composition varied across regions, with fields in the Northeast region showing a higher diversity. These results expand our knowledge of whitefly diversity in cassava and support the hypothesis that begomovirus epidemics have not occurred in cassava in Brazil due to the absence of competent vector Peer] reviewing PDF | (2021:02:57747:2:0:NEW 4 Jun 2021) 
populations. However, they indicate an ongoing adaptation process of BtMEAM1 to cassava, increasing the likelihood of begomovirus emergence in this crop. 
1 Assessing the diversity of whiteflies infesting cassava 2 in Brazil

3

4

5 Cesar A.D. Xavier ${ }^{1 a}$, Angélica Maria Nogueira ${ }^{1 b}$, Vinícius Henrique Bello², Luís Fernando

6 Maranho Watanabe ${ }^{2}$, Tarsiane Mara Carneiro Barbosa ${ }^{1}$, Miguel Alves Júnior ${ }^{3}$, Leonardo

7 Barbosa $^{4}$, José E.A. Beserra-Junior ${ }^{5}$, Alessandra Boari ${ }^{6}$, Renata Calegario ${ }^{7}$, Eduardo Silva

8 Gorayeb $^{8}$, Jaime Honorato Júnior ${ }^{9}$, Gabriel Koch ${ }^{7}$, Gaus Silvestre de Andreade Lima ${ }^{10}$, Cristian

9 Lopes $^{4}$, Raquel Neves de Mello ${ }^{11}$, Késsia Pantoja ${ }^{6}$, Fabio Nascimento Silva ${ }^{8}$, Roberto Ramos Sobrinho ${ }^{10 c}$, Enilton Nascimento Santana ${ }^{12}$, José Wilson Pereira da Silva ${ }^{13}$, Renate KrauseSakate $^{2}$, Francisco M. Zerbini ${ }^{1}$

${ }^{1}$ Dep. de Fitopatologia/BIOAGRO, Universidade Federal de Viçosa, Viçosa, MG, Brazil

${ }^{2}$ Dep. de Proteção Vegetal, Universidade Estadual Paulista, Botucatu, SP, Brazil

${ }^{3}$ Faculdade de Engenharia Agronômica, Universidade Federal do Pará, Altamira, PA, Brazil

${ }^{4}$ Instituto Federal do Sudeste de Minas Gerais, Rio Pomba, MG, Brazil

${ }^{5}$ Dep. de Fitotecnia, Universidade Federal do Piauí, Teresina, PI, Brazil

${ }^{6}$ Embrapa Amazônia Oriental, Belém, PA, Brazil

${ }^{7}$ Dep. de Fitotecnia e Fitossanidade, Universidade Federal do Paraná, Curitiba, PR, Brazil

${ }^{8}$ Centro de Ciências Agroveterinárias, Universidade do Estado de Santa Catarina, Lages, SC, Brazil

${ }^{9}$ Centro Multidisciplinar do Campus de Barra, Universidade Federal do Oeste da Bahia, Barra, BA, Brazil

${ }^{10}$ Centro de Ciências Agrárias/Fitossanidade, Universidade Federal de Alagoas, Rio Largo, AL, Brazil

${ }^{11}$ Embrapa Arroz e Feijão, Santo Antônio de Goiás, GO, Brazil

${ }^{12}$ Instituto Capixaba de Pesquisa e Extensão Rural, Linhares, ES, Brazil

${ }^{13}$ Faculdade de Engenharia Florestal, Universidade Federal do Pará, Altamira, PA, Brazil

a Present address: Department of Entomology and Plant Pathology, North Carolina State University, Raleigh, NC, United States

${ }^{\text {b }}$ Present address: Dep. de Proteção Vegetal, Universidade Estadual Paulista, Botucatu, SP, Brazil

${ }^{\mathrm{c}}$ Present address: School of Plant Sciences, University of Arizona, Tucson, AZ, United States

Corresponding Authors:

Renate Krause-Sakate 
40 Dep. de Proteção Vegetal, Universidade Estadual Paulista Júlio de Mesquita Filho, UNESP-

41 FCA, Botucatu, SP, Brazil

42 E-mail: renate.krause@unesp.br

43

44 F. Murilo Zerbini

45 Dep. de Fitopatologia/BIOAGRO, Universidade Federal de Viçosa, Viçosa, MG, Brazil

46 E-mail: zerbini@ufv.br

47

48

49

\section{Abstract}

Background. The necessity of a competent vector for transmission is a primary ecological factor driving the host range expansion of plant arthropod-borne viruses, with vectors playing an essential role in disease emergence. Cassava begomoviruses severely constrain cassava production in Africa. Curiously, begomoviruses have never been reported in cassava in South America, the center of origin for this crop. It has been hypothesized that the absence of a competent vector in cassava is the reason why begomoviruses have not emerged in South America.

Methods. We performed a country-wide whitefly diversity study in cassava in Brazil. Adults and/or nymphs of whiteflies were collected from sixty-six cassava fields in the main agroecological zones of the country. A total of 1,385 individuals were genotyped based on mitochondrial cytochrome oxidase I sequences.

61 Results. A high species richness was observed, with five previously described species and two putative new ones. The prevalent species were Tetraleurodes acaciae and Bemisia tuberculata, representing over $75 \%$ of the analyzed individuals. Although we detected, for the first time, the presence of Bemisia tabaci Middle East-Asia Minor 1 (BtMEAM1) colonizing cassava in Brazil, it was not prevalent. The species composition varied across regions, with fields in the Northeast region showing a higher diversity. These results expand our knowledge of whitefly diversity in cassava and support the hypothesis that begomovirus epidemics have not occurred in cassava in Brazil due to the absence of competent vector populations. However, they indicate an ongoing adaptation process of BtMEAM1 to cassava, increasing the likelihood of begomovirus emergence in this crop. 


\section{Introduction}

73 Cassava (Manihot esculenta Crantz) is a perennial shrub of the Euphorbiaceae family with great

74

75

76

77

78

79

80

81

82

83

84

85

86

87

88

89

90

91

92

93

94

95

96

97

98

99

100

101

102

103

104

105

106

107

108

109

110

111 economic and social importance, especially in Africa, Asia, and Latin America. Currently, cassava is the third most important source of calories after rice and corn and is a staple food for more than one billion of people living mainly in developing countries (Montagnac et al. 2009). Although the botanical and geographical origin of M. esculenta is still debated, studies based on genetic markers and archaeological evidence suggest that domesticated cassava originated from the wild relative progenitor M. esculenta ssp. flabellifolia in the Amazon basin, with the domestication center located at the southern border of the Amazon in Brazil (Clement et al. 2016; Leotard et al. 2009; Olsen \& Schaal 1999; Watling et al. 2018). After its introduction in west Africa by Portuguese traders during the $16^{\text {th }}$ century, cassava quickly disseminated throughout tropical Africa and Asia (Carter et al. 1997). Currently, the African continent is the world's biggest cassava producer, followed by Asia and South America (FAO, 2017). Due to its high resilience to adverse environmental conditions, especially drought, high yield per unit of land and low level of management and inputs required during its life cycle, cassava is a suitable crop for poor and small farmers, partially ensuring food security in many African countries (Alves \& Setter 2004; El-Sharkawy 2004; Gleadow et al. 2016).

Nevertheless, cassava may be affected by several pathogens and pests. Whiteflies (Hemiptera: Aleyrodidae) are one of the major constraints to its production in developing countries (Herrera Campo et al. 2011). Whiteflies comprise a diverse group of phloem-feeding insects, with more than 1,500 species assigned to 126 genera of which over 20 species have been reported to colonize cassava worldwide (Vasquez-Ordonez et al. 2015). In addition to the direct damage due feeding in the plant phloem, whiteflies cause indirect damage by deposition of honeydew, favoring the growth of sooty mold fungi on the leaf surface, and mainly by transmission of a broad range of viruses (Navas-Castillo et al. 2011). Currently, species included in the genera Aleurodicus, Aleurothrixus, Bemisia and Trialeurodes have been shown to constitute effective vectors of plant viruses classified in five families (Chandrashekar et al. 2020; Maruthi et al. 2017; Navas-Castillo et al. 2011; Njoroge et al. 2017). Aleurodicus dispersus and Aleurothrixus trachoides each transmit only one virus from the genera Ipomovirus and Begomovirus, respectively, while Trialeurodes vaporariorum and T. abutilonea transmit a few viruses included in the genera Crinivirus and Torradovirus. On the other hand, the Bemisia tabaci complex comprises one of the most important group of plant virus vectors, transmitting over 430 viruses, the majority included in the genus Begomovirus (Navas-Castillo et al. 2011; Zerbini et al. 2017) but including also viruses classified in the genera Carlavirus, Crinivirus, Ipomovirus, Polerovirus and Torradovirus (Ghosh et al. 2019; Gilbertson et al. 2015; Navas-Castillo et al. 2011; Whitfield et al. 2015).

Over the last decade, advances in the use of molecular markers has led to a deep reappraisal of the taxonomic status of B. tabaci (De Barro et al. 2011; Dinsdale et al. 2010). Based on 
112 molecular phylogeny of the mitochondrial cytochrome oxidase I (mtCOI) gene, it has been 113 proposed that $B$. tabaci consists of a complex of more than 40 cryptic (morphologically 114 indistinguishable) species (De Barro et al. 2011; Dinsdale et al. 2010; Lee et al. 2013; Mugerwa 115 et al. 2018; Vyskočilová et al. 2018). Partial or complete reproductive isolation and biological 116 and ecological differences among distinct species within the complex support the proposed 117 classification (De Marchi et al. 2017; Gilbertson et al. 2015; Malka et al. 2018; Qin et al. 2016). 118 The global dissemination of polyphagous and invasive species, such as $B$. tabaci Middle East119 Asia Minor 1 (BtMEAM1) and B. tabaci Mediterranean (BtMED), have caused major changes in the epidemiology of crop-infecting begomoviruses such as Tomato yellow leaf curl virus

121

122

123

124

125

126

127

128

129

130

131

132

133

134

135

136

137

138

139

140

141

142

143

144

145

146

147

148

149

150 (TYLCV), currently present in all the main tomato producing areas of the world (Lefeuvre et al. 2010; Mabvakure et al. 2016; Pan et al. 2012). In addition, the dissemination of polyphagous whiteflies has favored the transfer of indigenous begomoviruses from wild reservoir hosts to cultivated plants, as occurred in tomato crops in Brazil after the introduction of BtMEAM1 in the mid-1990's (Ribeiro et al. 1998; Rocha et al. 2013).

Specific associations between endemic populations of $B$. tabaci and indigenous begomoviruses have also led to the emergence of severe epidemic in crops (Fauquet \& Fargette 1990; Pan et al. 2018). Cassava mosaic disease (CMD) is considered the most significant constraint to cassava production in Africa (Jacobson et al. 2018; Rey \& Vanderschuren 2017) and has been expanding to south and southeast Asia in recent years (Minato et al. 2019; Wang et al. 2019; Wang et al. 2016). CMD is caused by viruses of the genus Begomovirus (family Geminiviridae), which are transmitted in a circulative manner by whiteflies of the Bemisia tabaci cryptic species complex (Zerbini et al. 2017). Also, because cassava can be vegetatively propagated, transmission by infected root stock is important for the long-distance spread of CMD (Wang et al. 2020). To date, nine cassava mosaic begomoviruses (CMBs) have been reported in association with CMD, seven of them in Africa and two in the Indian subcontinent (Jacobson et al. 2018; Legg et al. 2015; Patil \& Fauquet 2009). The emergence of CMD seems to have been the result of the transfer of indigenous begomoviruses from wild reservoir hosts to cassava, probably mediated by endemic populations of $B$. tabaci that have adapted to feed in cassava since its introduction from South America (Fauquet \& Fargette 1990; Legg \& Fauquet 2004). In Africa, CMD is transmitted primarily by B. tabaci Sub-Saharan Africa (SSA1-3, SSA6 and SSA9) and B. tabaci Indian Ocean (IO) (Jacobson et al. 2018; Kunz et al. 2019). B. tabaci MEAM1 has been detected in some countries and is associated mostly with the transmission of begomoviruses in tomato (Jacobson et al. 2018). Although wild reservoir hosts and a possible ancestral progenitor of current begomoviruses causing CMD have not been found, the absence of cassava-infecting begomoviruses in the Americas supports an African origin for those viruses, and the presence of cassava-adapted B. tabaci species being restricted to Africa reinforces that hypothesis. The high species diversity and high level of molecular variation observed in viral populations causing CMD strongly suggests Africa as a diversification center for CMBs, with distinct CMBs 
151 recurrently emerging and evolving for a long time (De Bruyn et al. 2016; De Bruyn et al. 2012;

152 Ndunguru et al. 2005; Tiendrebeogo et al. 2012).

153

154

155

156

157

158

159

160

161

162

163

164

165

166

167

168

169

170

171

172

173

174

175

176

177

178

179

180

181

182

183

184

185

186

187

188

189

190

Even if CMD in Africa is caused by indigenous viruses, the fact that cassava in South America has not been affected by begomoviruses is puzzling (Carabali et al. 2010; Carabali et al. 2008; Patil \& Fauquet 2009). Carabali et al. (2005) suggested that the absence of cassava-infecting begomoviruses in the Americas would be due to lack of competent $B$. tabaci species that efficiently colonize cassava (Fauquet \& Fargette 1990; Legg \& Fauquet 2004). In Colombia, the inability of B. tabaci MEAM1 to colonize M. esculenta efficiently has been demonstrated under experimental conditions, reinforcing the above hypothesis (Carabali et al. 2010). In addition, a recent study also from Colombia failed to detect any whitefly species of the B. tabaci complex in cassava (Gómez-Díaz et al. 2019).

Although whitefly diversity in Brazil has been surveyed extensively in recent years (Barbosa et al. 2015; Marubayashi et al. 2014; Marubayashi et al. 2013; Moraes et al. 2017; Moraes et al. 2018; Rocha et al. 2011), no study has been carried out specifically to explore the composition of whitefly communities colonizing cassava. Those studies carried out in other crops demonstrated that $B$. tabaci MEAM1 is the predominant species across Brazil in crops such as common bean, cotton, pepper, tomato and soybean. Furthermore, B. tabaci MED, which was recently introduced in Brazil, has quickly spread and currently is present in five states from the South and Southeast regions (Barbosa et al. 2015; Moraes et al. 2017; Moraes et al. 2018). A small number of whitefly samples from cassava were analyzed in those studies, with $B$. tuberculata and Tetraleurodes acaciae prevalent and detected exclusively in cassava (Marubayashi et al. 2014; Moraes et al. 2018). A large survey addressing whitefly diversity in cassava in its domestication center could provide clues to understand the absence of a CMD-like disease in the Americas. Moreover, this knowledge would be useful to anticipate the potential of emergence of begomoviruses in the crop and to help anticipate a management strategy.

Given this context, the objective of this work was to evaluate whitefly diversity in cassava across Brazil to infer about the absence of begomovirus occurrence in cassava. Our results demonstrated that the most prevalent species in cassava were T. acaciae and B. tuberculata. In addition, we detected for the first time the presence of BtMEAM1 colonizing cassava in Brazil. The possible implications of these findings are discussed considering the absence of CMD and the potential for its emergence in cassava fields in Brazil.

\section{Materials \& Methods}

\section{Whitefly and cassava samples}

Whiteflies were collected exclusively from cassava (M. esculenta) plants across 12 Brazilian states representative of the five macroregions (North, Northeast, Midwest, Southeast and South;

Peer] reviewing PDF | (2021:02:57747:2:0:NEW 4 Jun 2021) 
191 Figure 1) between March 2016 and February 2019 (Table 1). To gather evidence of whether a

192

193

194

195

196

197

198

199

200

201

202

203

204

205

206

207

208

209

210

211

212

213

214

215

216

217

218

219

220

221

222

223

224

225

226

227

228

229

230

given species was colonizing cassava, adults and nymphs from the same field were collected whenever possible (Table 1). Samples were obtained from commercial and non-commercial (subsistence) crops. Whitefly adults were sampled using a hand-held aspirator and nymphs were collected with the aid of a needle. Insects were preserved in $95 \%$ ethanol and stored at $-20^{\circ} \mathrm{C}$ until being used for molecular identification of the species.

To verify the presence of begomoviruses infecting cassava, foliar samples were also collected at some sampled sites (Suppl. Table S1). The samples were collected randomly regardless of the presence of virus-like symptoms. The leaves were press-dried and stored at room temperature as herbarium-like samples until being used for DNA extraction.

\section{Whitefly species identification}

Whitefly species were identified by sequencing of a mtCOI fragment, as previously described (Moraes et al. 2018). When enough adults and nymphs were collected at a given sampled site, ten individuals from each stage were analyzed, and when only one stage was obtained, 20 individuals were tested (Table 1). An initial assessment of whitely diversity was done using PCR-RFLP of the mtCOI fragment. When variation in the RFLP pattern was observed in the first screening, suggesting that more than one species could be present in that site, approximately five additional individuals for each stage were sequenced according to sample availability.

Total DNA was extracted from single individual whiteflies following a Chelex protocol (Walsh et al. 1991). Briefly, adults or nymphs were ground in $30 \mu \mathrm{l}$ of Chelex buffer $(5 \%$ Chelex in $1 \mathrm{x}$ Tris-EDTA) using a toothpick in a $600 \mu \mathrm{l}$ tube. Samples were vortexed for 30 seconds and incubated at $99^{\circ} \mathrm{C}$ for 8 min in a PTC-100 thermocycler (MJ Research). Next, the tubes were centrifuged at 14,000 g for $5 \mathrm{~min}$ and $20 \mu \mathrm{l}$ of the supernatant was collected and transferred to a new tube. One microliter of the supernatant was used as a template for PCR amplification of a $800 \mathrm{bp}$ fragment of the mtCOI gene using primers C1-J-2195 and L2-N-3014 (Frohlich et al. 1999; Simon et al. 1994). PCR was performed using $0.2 \mu \mathrm{M}$ of forward and reverse primers in a final volume of $25 \mu 1$ using GoTaq Colorless Master Mix (Promega), following the manufacturer's instructions. The PCR cycles consisted of an initial denaturing step at $95^{\circ} \mathrm{C}$ for 5 min, followed by 35 cycles at $95^{\circ} \mathrm{C}$ for $30 \mathrm{sec}, 42^{\circ} \mathrm{C}$ for $45 \mathrm{sec}$ and $72^{\circ} \mathrm{C}$ for $1 \mathrm{~min}$, with a final extension at $72^{\circ} \mathrm{C}$ for $10 \mathrm{~min}$. Amplified products were visualized in $0.8 \%$ agarose gels stained with ethidium bromide and directly used for RFLP analysis (Bosco et al. 2006).

RFLP analysis of the amplicons consisted of $5 \mu 1$ of each PCR product digested with 0.1 unit of TaqI (Promega) in a final volume of $20 \mu 1$. Reactions were performed at $65^{\circ} \mathrm{C}$ for 2 hours and visualized in $1.2 \%$ agarose gels stained with ethidium bromide. To verify whether the predicted mtCOI restriction pattern corresponded to a given species according to in silico prediction, a subset of PCR products from adults and nymphs representative of distinct patterns from different

PeerJ reviewing PDF | (2021:02:57747:2:0:NEW 4 Jun 2021) 
231

232

233

234

235

236

237

238

239

240

241

242

243

244

245

246

247

248

249

250

251

252

253

254

255

256

257

258

259

260

261

262

263

264

265

266

267

268

269

270

sampled sites were selected and sequenced. PCR products were precipitated with $100 \%$ ethanol and $3 \mathrm{M}$ sodium acetate pH 5.2 (Sambrook \& Russel 2001) and sequenced commercially (Macrogen Inc.) in both directions using primers C1-J-2195/L2-N-3014.

For a small subset of samples that failed to yield a PCR product using primers C1-J-2195 and L2-N-3014, a second screening, using a recently described primer set with improved specificity for species of the B. tabaci complex and B. afer (2195Bt and C012/Bt-sh2), was performed (Mugerwa et al. 2018). Samples that still failed to amplify or had unexpected RFLP pattern were analyzed with specific primers for T. vaporariorum (TvapF and Wfrev) (Scott et al. 2007).

\section{Sequence comparisons and phylogenetic analysis}

Nucleotide sequences were first checked for quality and assembled using Geneious v. 8.1 (Kearse et al. 2012). mtCOI sequences were initially analyzed with the BLAST $n$ algorithm (Altschul et al. 1990) to determine the whitefly species with which they shared greatest similarity. Pairwise comparisons between all $\mathrm{mtCOI}$ sequences obtained here and those with higher similarities (as determined by the BLAST $n$ search) were performed with the program SDT v. 1.2 (Muhire et al. 2014) using the MUSCLE alignment option (Edgar 2004).

For phylogenetic analyses, the final dataset was composed of 142 sequences: 95 obtained in this work and 47 sequences representative of species in the family Aleyrodidae. Sequences were retrieved from GenBank and from the updated mtCOI reference dataset for species of the Bemisia tabaci complex (Boykin et al. 2017). Multiple sequence alignments were prepared using the MUSCLE option in MEGA7 (Kumar et al. 2016). Alignments were checked and manually adjusted when necessary. Phylogenetic trees were constructed using Bayesian inference performed with MrBayes v. 3.0b4 (Ronquist \& Huelsenbeck 2003). The program MrModeltest v. 2.2 (Nylander 2004) was used to select the nucleotide substitution model with the best fit in the Akaike Information Criterion (AIC). The analyses were carried out running 50,000,000 generations with sampling at every 1,000 generations and a burn-in of $25 \%$. The convergence was assumed when average standard deviation of split frequencies was lower than 0.001 . Trees were visualized and edited using FigTree (tree.bio.ed.ac.uk/software/figtree) and CorelDRAW X5, respectively.

\section{Virus detection in foliar samples}

Total DNA was extracted as described (Doyle \& Doyle 1987) and used as a template for PCR using the DNA-A universal primer pair PAL1v1978 and PAR1c496 (Rojas et al. 1993). PCR was performed in a final volume of $25 \mu 1$ using Taq DNA Polymerase (Invitrogen) following the manufacturer's instructions. The PCR cycles consisted of an initial denaturing step at $95^{\circ} \mathrm{C}$ for 5 min, followed by 35 cycles at $95^{\circ} \mathrm{C}$ for $1 \mathrm{~min}, 52^{\circ} \mathrm{C}$ for $1 \mathrm{~min}$ and $72^{\circ} \mathrm{C}$ for $1 \mathrm{~min}$, with a final extension at $72^{\circ} \mathrm{C}$ for $10 \mathrm{~min}$. PCR products were visualized in $0.8 \%$ agarose gels stained with 
271 ethidium bromide. In addition, rolling-circle amplification (Inoue-Nagata et al. 2004) followed

272 by digestion with MspI was performed in a subset of the samples.

273

274 Diversity index and statical analysis

275 Simpson's index of diversity (1-D) was calculated to verify if there was any difference in

276 whitefly diversity across macroregions. This index represents the probability that two randomly

277 chosen individuals in a given sampled site will belong to distinct species (Morris et al. 2014).

278 Simpson's index was chosen as its value increases with increasing diversity and assigns more

279 weight to more abundant species in a sample. We assume that species colonizing cassava will be

280 in abundance, whereas rare species that briefly visit the plant without colonizing it will be

281 underrepresented. Simpson's index was calculated for each sampled site separately and then

282 pooled according to macroregions. To assess the statistical significance of the differences in

283 diversity among regions, the non-parametric Kruskal-Wallis test followed by post hoc multiple

284 comparison test using Fisher's least significant difference was calculated, using the function

285 kruskal implemented in the Agricolae package in R software (R Core Team 2017). Non-

286 parametric Spearman's rank correlation coefficient analysis was performed using the ggpubr

287 package in R software (R Core Team 2017).

288

289

\section{Results}

290

291

292

293

\section{High whitefly species richness in cassava in Brazil}

To verify the composition of whitefly communities colonizing cassava in Brazil, sampling was

294 performed across the country, including the main agroecological zones. A total of 66 sites from

295 12 states were sampled (Figure 1; Table 1). Out of 1,385 individuals submitted to PCR-RFLP

296

297 analysis, 58 adults and 37 nymphs from different locations and representing distinct restriction patterns were sequenced (Suppl. Table S2). The combination of PCR-RFLP followed by

298 sequencing showed reliability and consistence for species identification without misidentification due to incongruence between the two methods.

299

300

301

Based on pairwise comparisons and molecular phylogeny of the partial mtCOI gene, we

302 identified the presence of at least seven species comprising the whitefly community in cassava (Figure 2; Table 1). Among them, T. acaciae and B. tuberculata, both previously reported in this crop, were the most prevalent, representing over $75 \%$ of the analyzed individuals. In addition, based on the criterion of $3.5 \%$ divergence to differentiate species within the $B$. tabaci complex, three $B$. tabaci species were identified, with BtMED previously reported, and BtMEAM1 and $B t \mathrm{NW}$ identified for the first time in cassava fields in Brazil (Figure 2; Table 1). The species $B t$ MEAM1 represented $18 \%$ of the total individuals analyzed, followed by $B t$ MED $(1.6 \%)$ and $308 B t \mathrm{NW}(0.21 \%)$. 
310 Furthermore, two putative new species were identified (Figure 2), provisionally named whitefly

311

312

313

314

315

316

317

318

319

320

321

322

323

324

325

326

327

328

329

330

331

332

333

334

335

336

337

338

339

340

341

342

343

344

345

346

347

348

349 new species 1 and 2 (WtNEW1 and WtNEW2). The WtNEW1 mtCOI sequence (KY249522) showed highest identity $(80.65 \%)$ and clustered close to the $T$. acaciae clade, comprised of individuals reported here and three other previously reported sequences from cassava in Brazil (Figure 2). For WtNEW2, two mtCOI sequences obtained from an adult (JX678666) and a nymph (DQ989531) shared 97.81\% among them and showed highest identity with $B$. tabaci (adult: $82.11 \%$; nymph: $81.68 \%$ ) and clustered as a basal sister clade to the genus Bemisia (Figure 2). Although whitefly taxonomy is predominantly based on puparial characters (Hodges $\&$ Evans 2005) and there is no taxonomic criterion established based in mtCOI sequences for most of the groups, as has been proposed for the $B$. tabaci complex, the level of divergence between the two proposed new species with the closest species is similar to the level of divergence observed between species already described within the Aleyrodidae, as demonstrated in pairwise comparisons (Suppl. Table S3) and phylogenetic analysis (Figure 2). Nevertheless, further molecular and morphological characterization should be performed. Together, these results indicate the existence of a high whitefly species richness in cassava in Brazil.

\section{Both the prevalence and the capacity to colonize cassava differ among species}

Nymphs were collected for samples identified as T. acaciae, B. tuberculata, BtMEAM1 and the two new putative species (Figure 3A), suggesting that these species may colonize cassava. Nymphs were not obtained at two sites where BtMED was prevalent (SP1 and SP12). Although it could be suggested that this species has the potential to colonize cassava due to the high prevalence of adults at these two sites, the lack of nymphs suggests otherwise. Moreover, at the sites PR4 and MT6, BtMEAM1 predominated among adults but $100 \%$ of the nymphs were $B$. tuberculata, suggesting that the predominance at one stage does not necessarily mean predominance in another stage. Indeed, correlation analysis between the number of adults and nymphs, performed for all sites where both stages were sampled, showed no significant correlation between them (Suppl. Figure S1). Further sampling in those sites or free-choice experiments are necessary to confirm the potential of $B t$ MED to colonize cassava. Considering the whole sampling, we detected only three adults of $B t \mathrm{NW}$, suggesting an inability of this specie to colonize cassava.

To verify if prevalence differs among species across distinct developmental stages, the data were separated according to stage and the proportions of individuals were compared for the three most abundant species (Figure 3B, C). Considering the entire data set, T. acaciae was the prevalent species, followed by $B$. tuberculata and BtMEAM1 $\left(x_{2}^{2}=152.63, P<2.2 \times 10^{-16}\right)$. The same was true according to stage, either adults $\left(x_{2}^{2}=28.61, P<6.1 \times 10^{-07}\right)$ or nymphs $\left(x_{2}^{2}=169.44, P\right.$ $<2.2 \times 10^{-16}$; Figure $3 \mathrm{~B}$ ). However, caution is needed to interpret these results as only adults were sampled at some sites where BtMEAM1 and B. tuberculata were prevalent (Figure 3A), which could bias the analysis, causing an underestimation of the number of nymphs for those species. Therefore, we also analyzed the data considering only those sites where both adults and nymphs 
350

351

352

353

354

355

356

357

358

359

360

361

362

363

364

365

366

367

368

369

370

371

372

373

374

375

376

377

378

379

380

381

382

383

384

385

386

387

were obtained. Again, T. acaciae was the predominant species followed by B. tuberculata and $B t$ MEAM1 considering either the entire data set $\left(x_{2}^{2}=258.61, P<2.2 \times 10^{-16}\right)$ or only nymphs $\left(x_{2}^{2}\right.$ $\left.=164.47, P<2.2 \times 10^{-16}\right)$. When only adults were considered, $T$. acaciae was still predominant $\left(x_{2}^{2}\right.$ $\left.=113.52, P<2.2 \times 10^{-16}\right)$ but no difference between $B$. tuberculata and BtMEAM1 was observed ( $x_{1}^{2}=0.505, P=0.477$; Figure $3 C$ ). Moreover, it could be argued that samples from Minas Gerais (MG) were overrepresented in our sampling (Figure 1C), which could also bias the results presented above due to the predominance of T. acaciae in this state (Figure 3A). To test this possibility, we analyzed the data excluding the samples from MG. In this case, when both stages were considered, $B$. tuberculata was predominant $\left(x_{2}^{2}=62.09, P=3.3 \times 10^{-14}\right)$ but no difference between T. acaciae and BtMEAM1 was observed $\left(x_{1}^{2}=1.91, P=0.166\right)$. When each stage was considered separately, B. tuberculata was predominant followed by BtMEAM1 and T. acaciae (adults: $x_{2}^{2}=43.94, P=2.9 \times 10^{-10}$; nymphs: $x_{2}^{2}=84.19, P<2.2 \times 10^{-16}$ ). Together, these results indicate that the potential to colonize cassava differs among species, which could be due either to lower preference for the plant or to differences in the competitive ability among species during cassava colonization. In addition, they reinforce the low efficiency of $B t$ MEAM1 to colonize cassava.

\section{Competitive interference does not explain the differences in prevalence}

Interestingly, at least two species were detected co-occurring at $51 \%$ of the sampled sites (Figure $3 \mathrm{~A})$. To verify the possibility of competition among T. acaciae, B. tuberculata and BtMEAM1 to explain the observed differences in prevalence (instead of differences in host preference), the competitive capacity of these three species was inferred based on the analysis of predominance at the sites where they occurred together. Initially, we verified if there were any differences in incidence, defined here as the number of sampled sites where at least one individual belonging to one of the three species was detected (Figure 4A). The results demonstrate that there were no differences in incidence among them $\left(x_{2}^{2}=1.25, P=0.537\right.$; Figure $\left.4 \mathrm{~A}\right)$. In addition, no differences were observed when the proportion of sites where whitefly species occurred alone or in different combinations was compared $\left(x_{6}^{2}=3.26, P=0.776\right.$; Figure $\left.4 \mathrm{~B}\right)$. However, when we compared the occurrence between $B t$ MEAM1 and non- $B$. tabaci species at the sites where they occur alone, the number of sites with non- $B$. tabaci species was higher $\left(x_{1}^{2}=6.53, P=0.011\right.$; Figure 4B). Thus, the competitive capacity was inferred based on the proportion of individuals from each species at the fields where these species were detected co-occurring in different combinations (Figure 4C). Interestingly, at the sites where BtMEAM1 and B. tuberculata were sampled together, $B$. tuberculata predominated over $B t$ MEAM1, suggesting higher competitive potential (Figure $4 C$ ). For all other species combinations, no evidence of differences in competitive capacity were observed (Figure 4C). Together, these results suggest that, rather than competition, lower host preference by $B t$ MEAM1 explains its non-prevalence compared to $T$. acaciae and B. tuberculata, resulting in low colonization rate as indicated by the low number of $B t$ MEAM1 nymphs detected in cassava (Figure 3).

Peerj reviewing PDF | (2021:02:57747:2:0:NEW 4 Jun 2021) 
388

389

390

391

392

393

394

395

396

397

398

399

400

401

402

403

404

405

406

407

408

409

410

411

412

413

414

415

416

417

418

419

420

421

422

423

424

425

426

427

\section{Composition and species diversity of whiteflies differ among Brazilian regions}

The predominance of species composing the whitefly community across macroregions varied considerably. While $T$. acaciae predominated in the North, Southeast and Northeast, it was not detected in the Midwest (Figure 5A). In addition, B. tuberculata was detected in all regions, and was prevalent in the South and Midwest. BtMEAM1, although not prevalent in any of the regions, was also detected in all regions. Although the number of species detected was higher in the Southeast, where six species out seven were detected, whitefly diversity was significantly higher in fields in the Northeast according to Simpson's index of diversity (Figure 5B), with no differences among the other four regions.

\section{No begomoviruses detected infecting cassava}

To verify the presence of begomoviruses infecting cassava, we analyzed leaves sampled in some of the fields where whiteflies were collected (Suppl. Table S1). Based on PCR detection using universal primers for begomoviruses, all plants were negative. Although the possibility of false negatives cannot be completely discarded, it is unlikely since the PCR assay used primers known to detect CMBs (Berrie et al. 2001; Rojas et al. 1993; Zhou et al. 1997) and none of the plants displayed symptoms (Suppl. Table S1). Nevertheless, as a confirmatory step, we performed RCA followed by digestion with MspI in five samples, all with negative results (Suppl. Table S1).

\section{Discussion}

Vectors play an essential role during the life cycle of plant viruses, directly affecting their ecology and evolution (Gallet et al. 2018; Gutierrez \& Zwart 2018; Sacristan et al. 2003). Usually, a group of plant viruses establishes a very specific interaction with only one or a few related species of vectors, making virus ecology strongly dependent on that of its vector (Gallet et al. 2018). It has been suggested that the natural host range of a virus is dependent on its vector's host range, as most plant viruses have greater specificity for the vector than for the plant host (Dietzgen et al. 2016; Elena et al. 2014). Indeed, the existence of a competent vector for transmission and able to colonize potential reservoir and recipient new hosts is a primary ecological factor driving host range expansion of viruses. Thus, vectors play an essential role during viral disease emergence and epidemics (Elena et al. 2014; Fereres 2015; Gilbertson et al. 2015; Navas-Castillo et al. 2011). Understanding ecological factors, such as vector species dynamics in crops, might provide important clues about historical and current events of emergence or re-emergence of viral diseases, and even anticipate the potential for new ones to occur (Legg et al. 2014).

Although it could be suggested that there are no begomoviruses capable of infecting cassava in the Americas, the high diversity of begomoviruses reported in a broad range of cultivated and non-cultivated plants in several botanical families, including the Euphorbiaceae, make this highly unlikely (Albuquerque et al. 2012a; Albuquerque et al. 2012b; Castillo-Urquiza et al. 
428

429

430

431

432

433

434

435

436

437

438

439

440

441

442

443

444

445

446

447

448

449

450

451

452

453

454

455

456

457

458

459

460

461

462

463

464

465

466

467

2008; Fernandes et al. 2008; Fernandes et al. 2011; Macedo et al. 2018; Mar et al. 2017b; PazCarrasco et al. 2014; Rocha et al. 2013; Rodríguez-Negrete et al. 2019). Besides, CMBs could be introduced from infected rootstocks, as demonstrated by the introduction of Sri Lankan cassava mosaic virus into China (Wang et al. 2020; Wang et al. 2019). Thus, the absence of a competent vector able to colonize cassava and transfer begomoviruses from wild plants to cassava, as previously suggested (Carabali et al. 2005), seems to be a more plausible hypothesis to explain the lack of begomovirus epidemics in this crop.

Our country-wide survey of whiteflies associated with cassava in Brazil uncovered a high degree of species diversity and showed that $T$. acaciae and B. tuberculata are the prevalent species across the country. Non- $B$. tabaci species, including $B$. tuberculata, have been shown to be prevalent also in Colombia (Gómez-Díaz et al. 2019). In contrast, in Africa, endemic species of the B. tabaci complex are prevalent in cassava (Jacobson et al. 2018; Legg et al. 2014; TockoMarabena et al. 2017). Previous studies surveying whitefly diversity in South American countries failed to detect $T$. acaciae and B. tuberculata in crops other than cassava, indicating a very narrow host range, which may in fact be restricted to cassava or at least to cultivated plants (Alemandri et al. 2015; Marubayashi et al. 2014; Moraes et al. 2018).

$B t \mathrm{MEAM} 1$ and $B t \mathrm{NW}$ are reported here for the first time in cassava in Brazil. BtMEAM1 was the third most prevalent species, representing $18 \%$ of the genotyped individuals, and with similar incidence to $T$. acaciae and B. tuberculata. The failure of previous studies to detect BtMEAM1 in cassava may have been due to the small number of samples analyzed. The wide distribution and prevalence of BtMEAM1 in the main agroecological zones in Brazil has been well established, mostly in association with annual crops such as soybean, cotton, common bean and tomato (Moraes et al. 2018). In these crops, BtMEAM1 has a great reproductive capacity, rapidly increasing its population. Interestingly, our data showed the higher prevalence of BtMEAM1 to be in the Midwest, where extensive agriculture predominates. The harvest of annual crops in the Midwest might cause the migration of the insect to semiperennial hosts such as cassava, which could explain why in some sites where BtMEAM1 predominated among adults, it was not detected as nymphs (e.g., sites MT5, MT6, PR4).

It will be important to monitor $B t$ MEAM1 populations in cassava over the next years, to assess its possible adaptation to this host. The fact that we collected BtMEAM1 nymphs at several locations suggests that this process may already be under way. We also detected BtMED, a worrying result given the recent introduction of this species in the Brazil and its potential to displace other species, including BtMEAM1 (Liu et al. 2012; Sun et al. 2013; Watanabe et al. 2019). BtMED has disseminated quickly in the country, mainly in association with ornamental plants in greenhouses (Moraes et al. 2018). Even though we detect BtMED associated to cassava, we cannot infer its potential to effectively colonize this host since only adults were collected. The third species detected is the indigenous $B t$ NW. Although $B t$ MEAM1 partially displaced 
468

469

470

471

472

473

474

475

476

477

478

479

480

481

482

483

484

485

486

487

488

489

490

491

492

493

494

495

496

497

498

499

500

501

502

503

504

505

506

507

$B t \mathrm{NW}$ in Brazil, this species can still be sporadically detected, mostly in association with noncultivated hosts (Marubayashi et al. 2014; Marubayashi et al. 2013; Moraes et al. 2018). It has been recurrently detected in Euphorbia heterophylla, suggesting a potential to colonize other species in the family Euphorbiaceae. However, the very low frequence with which it was detected and the absence of nymphs indicate that $B t \mathrm{NW}$ is poorly adapted to cassava.

The identification of two putative new species highlights the remarkable genetic diversity of whiteflies. Interestingly, one of the new species was collected in the state of Mato Grosso, which corresponds to the region considered to be the domestication center of cassava (Clement et al. 2016; Leotard et al. 2009; Olsen \& Schaal 1999; Watling et al. 2018). Further studies are needed to explore plant biodiversity in this region (Nassar 2001; Olsen 2004), which might reveal a similar diversity of whiteflies which may be specifically adapted to non-cultivated plant species due to long term co-evolution. The close phylogenetic relationship of the new species with nonB. tabaci whiteflies suggests that they are not virus vectors.

Whitefly species richness in cassava is just starting to be assessed and may be greater than reported here. Based on morphological characters, Alonso et al. (2012) reported the presence of Aleurothrixus aepim and Trialeurodes manihoti colonizing cassava in the state of Rio de Janeiro. Although we did not analyze samples from that region, the failure to detect these species in other states suggests a restricted occurrence. Moreover, morphological characters alone are not always sufficient to classify whiteflies at the species level, and additional studies using molecular tools are needed to assess these molecularly uncharacterized whiteflies species (Dickey et al. 2015).

Host suitability has been shown to be an important factor influencing the competitive capacity among species of the B. tabaci complex (Luan et al. 2012; Sun et al. 2013; Watanabe et al. 2019). Watanabe et al. (2019) demonstrated that displacement capacity between two invasive $B$. tabaci species was dependent on host suitability. While BtMEAM1 displaced BtMED only on tomato, BtMED displaced BtMEAM1 on sweet pepper and common bean. Luan et al. (2012) demonstrated that even in a host plant poorly suitable for BtMEAM1, it was able to displace an indigenous species challenger. These authors demonstrated that even though host suitability may affect the speed of displacement, it may not affect the direction, as BtMEAM1 always won the challenge (Luan et al. 2012). Interestingly, two or more species occurring sympatrically were detected in $51 \%$ of the fields analyzed in our study. In sites where BtMEAM1 and B. tuberculata co-occurred, B. tuberculata predominated, suggesting a higher competitive capacity.

Nonetheless, in all other combinations of co-occurring species, no differences in prevalence were observed. Thus, competitive capacity is unlikely to explain the low prevalence of BtMEAM1, or the differences observed between $T$. acaciae and B. tuberculata. However, we collected whiteflies in a single point in time at each location. Since competition is a dynamic process, additional surveys should be conducted in the future to further confirm these observations. 
508 Host adaptation may be a more important component affecting the low predominance of

509

510

511

512

513

514

515

516

517

518

519

520

521

522

523

524

525

526

527

528

529

530

531

532

533

534

535

536

537

538

539

540

541

542

543

544

545

546

547

$B t$ MEAM1 in cassava, as previously suggested (Carabali et al. 2005). The inability of

$B t$ MEAM1 and $B t$ MED to colonize domesticated cassava efficiently has been demonstrated under experimental conditions (Carabali et al. 2010; Carabali et al. 2008; Milenovic et al. 2019; Vyskočilová et al. 2019). Carabali et al. (2008), evaluating the colonization potential of $B t$ MEAM1 in three commercial cassava genotypes, demonstrated that only in one of them did $B t$ MEAM1 complete its development cycle from eggs to adult, and even then, at very low rates $(0.003 \%)$. Using an electrical penetration graph assay, Milenovic et al. (2019) demonstrated the inability of $B t$ MED to feed in cassava plants. Adults of this species spent a very short time ingesting cassava phloem sap compared to sap from a suitable host, suggesting that they would die by starvation in the field. Furthermore, the low efficiency of whiteflies of the $B t$ MED mitochondrial subgroups Q1 and Q2 in using cassava as a host has also been demonstrated (Vyskočilová et al. 2019). Oviposition and adult survival rates were very low, and development from eggs to adults was not observed. Although these studies were conducted under experimental conditions, the low predominance of BtMEAM1 and BtMED shown here and in other field surveys in Africa (Ghosh et al. 2015; Tajebe et al. 2015; Tocko-Marabena et al. 2017) strongly indicates a low adaptation of these species to cassava.

Nevertheless, our results indicate an ongoing adaptation process of BtMEAM1 to cassava, with the detection of nymphs and adults in the same field. Interestingly, Carabali et al. (2005) demonstrated a gradual increase in the rate of reproduction and development of BtMEAM1 after successive passages on plants phylogenetically related to the genus Manihot (Euphorbia pulcherrima and Jatropha gossypiifolia), indicating the potential of this whitefly species to become adapted to cassava through intermediate hosts. Furthermore, successful reproduction in the wild relative M. esculenta ssp. flabellifolia indicates that this plant may constitute an intermediate host leading to adaptation (Carabali et al. 2010). This plant has been reported to be widely spread in the Amazon basin and the Midwest region of Brazil (Olsen 2004). Interestingly, our data showed the higher prevalence of BtMEAM1 to be in the Midwest. Although we cannot establish a cause and effect relationship, it is reasonable to speculate that M. esculenta ssp.

flabellifolia could be acting as an intermediate host mediating adaptation. A survey addressing whitefly diversity in this host should be necessary to test this hypothesis.

In Brazil, cassava is predominantly grown as a subsistence crop, usually side by side with other vegetables and with a high incidence of weeds. Growing cassava in a heterogenous environment, especially in the presence of related plants, may increase the adaptation potential of BtMEAM1 and other species of the complex such as $B t \mathrm{MED}$, which we also detected in the open field. A high diversity of plants in cassava fields may allow an overlapping of ecological niches for distinct whitefly species, which under enough selection pressure may gradually adapt to new hosts. The sympatric occurrence of T. acaciae, B. tuberculata and BtMEAM1, supports the role of botanical heterogeneity in shaping the composition of whitefly populations associated with

Peerj reviewing PDF | (2021:02:57747:2:0:NEW 4 Jun 2021) 
548

549

550

551

552

553

554

555

556

557

558

559

560

561

562

563

564

565

566

567

568

569

570

571

572

573

574

575

576

577

578

579

580

581

582

583

584

585

586

587

cassava. A similar pattern was observed in Colombia, with $66 \%$ of the surveyed sites showing at least two species occurring sympatrically (Gómez-Díaz et al. 2019). Moreover, a predominance of one species in a given developmental stage and a different one in another stage (e.g., nymphs $v s$ adults) at the same site suggests that other hosts may sustain reproduction and development, with adults migrating to cassava.

Euphorbia heterophylla (family Euphorbiaceae) is an invasive weed widely spread across Brazil and associated with several crops (Mar et al. 2017b; Wilson 1981). The presence of $E$. heterophylla plants in association with cassava (Figure 1A) and the fact that it was the most suitable host for BtMEAM1 in Brazil out seven tested (Sottoriva et al. 2014) shows its potential to act as an intermediate host mediating BtMEAM1 adaptation. E. heterophylla has been frequently associated with the begomovirus Euphorbia yellow mosaic virus (EuYMV) (Mar et al. 2017b). Barreto et al. (2013) demonstrated that this plant is also a host of Tomato severe rugose virus (ToSRV), which even at a very low titer was transmitted to tomato plants, demonstrating the potential of $E$. heterophylla to act as a reservoir host. Surprisingly, considering that $E$. heterophylla and tomato belong to distinct botanical families, EuYMV is able to infect tomato (Barreto et al. 2013). The closer botanical relationship between E. heterophylla and cassava may indicate a higher potential of EuYMV to infect cassava. The presence of EuYMV-infected $E$. heterophylla in cassava fields, as observed in this study (Figure 1A), its suitability as a host for $B t$ MEAM1, and the high efficiency of EuYMV transmission by BtMEAM1 (Mar et al. 2017a), suggest that EuYMV may have spillover potential to cassava. Experiments are ongoing in our laboratory to assess this spillover potential.

The emergence of begomoviruses in tomato crops in Brazil followed the introduction of BtMEAM1 (Ribeiro et al. 1998; Rocha et al. 2013), demonstrating the role of vector populations in promoting viral host range expansion and consequently epidemics. Thus, the adaptation of whiteflies to cassava could facilitate the emergence of begomoviruses in this crop. The establishment of management strategies to prevent or at least delaying the adaptation process is therefore necessary. Bemisia tabaci species may disperse across long distances international trade routes (Hadjistylli et al. 2016). Thus, preventing the introduction of cassava-adapted $B$. tabaci species from Africa should also be a priority.

\section{Conclusions}

We hypothesized that the absence of cassava-infecting begomoviruses in Brazil would be due to lack of competent $B$. tabaci vector species that efficiently colonize cassava. The results of our country-wide survey provide support to this hypothesis, with the most prevalent species being the non-vectors Tetraleurodes acaciae and Bemisia tuberculata. However, we did detect the presence of adults insects of Bemisia tabaci MEAM1, suggesting an ongoing adaptation process of this species to cassava which could facilitate the emergence of begomoviruses in this crop. Management strategies to prevent or at least delay the adaptation process are necessary. 


\section{References}

590

591

592

593

594

595

596

597

598

599

600

601

602

603

604

605

606

607

608

609

610

611

612

613

614

615

616

617

618

619

620

621

622

623

624

625

626

627

628

629

630

631

632

633

634

635

636

Albuquerque LC, Inoue-Nagata AK, Pinheiro B, Resende RO, Moriones E, and Navas-Castillo J. 2012a. Genetic diversity and recombination analysis of sweepoviruses from Brazil. Virology Journal 9:241.

Albuquerque LC, Varsani A, Fernandes FR, Pinheiro B, Martin DP, Ferreira PTO, Lemos TO, and InoueNagata AK. 2012b. Further characterization of tomato-infecting begomoviruses in Brazil. Archives of Virology 157:747-752. 10.1007/s00705-011-1213-7

Alemandri V, Vaghi Medina CG, Dumon AD, Arguello Caro EB, Mattio MF, Garcia Medina S, Lopez Lambertini PM, and Truol G. 2015. Three members of the Bemisia tabaci (Hemiptera: Aleyrodidae) cryptic species complex occur sympatrically in Argentine horticultural crops. Journal of Economic Entomology 108:405-413.

Alonso RS, Racca-Filho F, and Lima AF. 2012. Occurrence of whiteflies (Hemiptera: Aleyrodidae) on cassava (Manihot esculenta Crantz) crops under field conditions in the state of Rio de Janeiro, Brazil. EntomoBrasilis 5:2.

Altschul SF, Gish W, Miller W, Myers EW, and Lipman DJ. 1990. Basic local alignment search tool. Journal of Molecular Biology 215:403-410.

Alves AAC, and Setter TL. 2004. Response of cassava leaf area expansion to water deficit: cell proliferation, cell expansion and delayed development. Annals of Botany 94:605-613. 10.1093/aob/mch179

Barbosa LF, Yuki VA, Marubayashi JM, De Marchi BR, Perini FL, Pavan MA, Barros DR, Ghanim M, Moriones E, Navas-Castillo J, and Krause-Sakate R. 2015. First report of Bemisia tabaci Mediterranean (Q biotype) species in Brazil. Pest Management Science 71:501-504. 10.1002/ps.3909

Barreto SS, Hallwass M, Aquino OM, and Inoue-Nagata AK. 2013. A study of weeds as potential inoculum sources for a tomato-infecting begomovirus in central Brazil. Phytopathology 103:436-444. 10.1094/phyto-07-12-0174-r

Berrie LC, Rybicki EP, and Rey MEC. 2001. Complete nucleotide sequence and host range of South African cassava mosaic virus: Further evidence for recombination amongst begomoviruses. Journal of General Virology 82:53-58.

Bosco D, Loria A, Sartor C, and Cenis JL. 2006. PCR-RFLP identification of Bemisia tabaci biotypes in the Mediterranean Basin. Phytoparasitica 34:243.

Boykin LM, Savill A, and De Barro P. 2017. Updated mtCOI reference dataset for the Bemisia tabaci species complex. F1000 Research 6:1835. 10.12688/f1000research.12858.1

Carabali A, Belloti AC, and Montoya-Lerma J. 2010. Biological parameters of Bemisia tabaci (Gennadius) biotype B (Hemiptera: Aleyrodidae) on Jatropha gossypiifolia, commercial (Manihot esculenta) and wild cassava (Manihot flabellifolia and M. carthaginensis) (Euphorbiaceae). Neotropical Entomology 39:562-567.

Carabali A, Bellotti AC, Montoya-Lerma J, and Cuellar ME. 2005. Adaptation of Bemisia tabaci biotype B (Gennadius) to cassava, Manihot esculenta (Crantz). Crop Protection 24:643-649.

Carabali A, Montoya-Lerma J, and Bellotti AC. 2008. Development and reproduction of Bemisia tabaci "B" (Hemiptera : Aleyrodidae) on cassava (Manihot esculenta) genotypes. Revista Colombiana de Entomologia 34:28-32.

Carter SE, Fresco LO, Jones PG, and Fairbairn JN. 1997. Introduction and diffusion of cassava in Africa. IITA Research Guide no. 49. Ibadan, Nigeria: International Institute of Tropical Agriculture (IITA).

Castillo-Urquiza GP, Beserra Jr. JEA, Bruckner FP, Lima ATM, Varsani A, Alfenas-Zerbini P, and Zerbini FM. 2008. Six novel begomoviruses infecting tomato and associated weeds in Southeastern Brazil. Archives of Virology 153:1985-1989. 10.1007/s00705-008-0172-0

PeerJ reviewing PDF | (2021:02:57747:2:0:NEW 4 Jun 2021) 
637

638

639

640

641

642

643

644

645

646

647

648

649

650

651

652

653

654

655

656

657

658

659

660

661

662

663

664

665

666

667

668

669

670

671

672

673

674

675

676

677

678

679

680

681

682

683

684

685

686
Chandrashekar K, Rao A, Gorane A, Verma R, and Tripathi S. 2020. Aleurothrixus trachoides (Back) can transmit begomovirus from Duranta to potato, tomato and bell pepper. Journal of Biosciences 45:36.

Clement CR, Rodrigues DP, Alves-Pereira A, Mühlen GS, Cristo-Araújo Md, Moreira PA, Lins J, and Reis VM. 2016. Crop domestication in the upper Madeira River basin. Boletim do Museu Paraense Emílio Goeldi Ciências Humanas 11:193-205.

De Barro PJ, Liu SS, Boykin LM, and Dinsdale AB. 2011. Bemisia tabaci: A statement of species status. Annual Review of Entomology 56:1-19.

De Bruyn A, Harimalala M, Zinga I, Mabvakure BM, Hoareau M, Ravigne V, Walters M, Reynaud B, Varsani A, Harkins GW, Martin DP, Lett JM, and Lefeuvre P. 2016. Divergent evolutionary and epidemiological dynamics of cassava mosaic geminiviruses in Madagascar. BMC Evolutionary Biology 16:182. 10.1186/s12862-016-0749-2

De Bruyn A, Villemot J, Lefeuvre P, Villar E, Hoareau M, Harimalala M, Abdoul-Karime AL, AbdouChakour C, Reynaud B, Harkins GW, Varsani A, Martin DP, and Lett JM. 2012. East African cassava mosaic-like viruses from Africa to Indian ocean islands: molecular diversity, evolutionary history and geographical dissemination of a bipartite begomovirus. BMC Evolutionary Biology 12:228. 10.1186/1471-2148-12-228

De Marchi BR, Marubayashi JM, Favara GM, Yuki VA, Watanabe LFM, Barbosa LF, Pavan MA, and Krause-Sakate R. 2017. Comparative transmission of five viruses by Bemisia tabaci NW2 and MEAM1. Tropical Plant Pathology 42:495-499. 10.1007/s40858-017-0186-9

Dickey AM, Stocks IC, Smith T, Osborne L, and McKenzie CL. 2015. DNA Barcode Development for Three Recent Exotic Whitefly (Hemiptera: Aleyrodidae) Invaders in Florida. Florida Entomologist 98:473-478, 476.

Dietzgen RG, Mann KS, and Johnson KN. 2016. Plant virus-insect vector interactions: current and potential future research directions. Viruses 8:303. 10.3390/v8110303

Dinsdale A, Cook L, Riginos C, Buckley YM, and De Barro P. 2010. Refined global analysis of Bemisia tabaci (Hemiptera: Sternorrhyncha: Aleyrodoidea: Aleyrodidae) mitochondrial cytochrome oxidase 1 to identify species level genetic boundaries. Annals of the Entomological Society of America 103:196-208. 10.1603/an09061

Doyle JJ, and Doyle JL. 1987. A rapid DNA isolation procedure for small amounts of fresh leaf tissue. Phytochemical Bulletin 19:11-15.

Edgar RC. 2004. MUSCLE: a multiple sequence alignment method with reduced time and space complexity. BMC Bioinformatics 5:1-19. 10.1186/1471-2105-5-113

El-Sharkawy MA. 2004. Cassava biology and physiology. Plant Molecular Biology 56:481-501.

Elena SF, Fraile A, and Garcia-Arenal F. 2014. Evolution and emergence of plant viruses. Advances in Virus Research 88:161-191. 10.1016/B978-0-12-800098-4.00003-9

Fauquet C, and Fargette D. 1990. African cassava mosaic virus: etiology, epidemiology and control. Plant Disease 74:404-411.

Fereres A. 2015. Insect vectors as drivers of plant virus emergence. Current Opinion in Virology 10:42-46.

Fernandes FR, Albuquerque LC, Giordano LB, Boiteux LS, Ávila AC, and Inoue-Nagata AK. 2008. Diversity and prevalence of Brazilian bipartite begomovirus species associated to tomatoes. Virus Genes 36:251-258. 10.1007/s11262-007-0184-y

Fernandes FR, Albuquerque LC, Oliveira CL, Cruz ARR, Rocha WB, Pereira TG, Naito FYB, Dias ND, Nagata T, Faria JC, Zerbini FM, Aragão FJL, and Inoue-Nagata AK. 2011. Molecular and biological characterization of a new Brazilian begomovirus, euphorbia yellow mosaic virus (EuYMV), infecting Euphorbia heterophylla plants. Archives of Virology 156:2063-2069. 10.1007/s00705-011-1070-4

Frohlich DR, Torres-Jerez II, Bedford ID, Markham PG, and Brown JK. 1999. A phylogeographical analysis of the Bemisia tabaci species complex based on mitochondrial DNA markers. Molecular Ecology 8:1683-1691.

Peer) reviewing PDF | (2021:02:57747:2:0:NEW 4 Jun 2021) 
687

688

689

690

691

692

693

694

695

696

697

698

699

700

701

702

703

704

705

706

707

708

709

710

711

712

713

714

715

716

717

718

719

720

721

722

723

724

725

726

727

728

729

730

731

732

733

734

735

736

737

Gallet R, Michalakis Y, and Blanc S. 2018. Vector-transmission of plant viruses and constraints imposed by virus-vector interactions. Current Opinion in Virology 33:144-150. 10.1016/j.coviro.2018.08.005

Ghosh S, Bouvaine S, and Maruthi MN. 2015. Prevalence and genetic diversity of endosymbiotic bacteria infecting cassava whiteflies in Africa. BMC Microbiology 15:93. 10.1186/s12866-015-0425-5

Ghosh S, Kanakala S, Lebedev G, Kontsedalov S, Silverman D, Alon T, Mor N, Sela N, Luria N, Dombrovsky A, Mawassi M, Haviv S, Czosnek H, and Ghanim M. 2019. Transmission of a new polerovirus infecting pepper by the whitefly Bemisia tabaci. Journal of Virology 15:e00488-00419.

Gilbertson RL, Batuman O, Webster CG, and Adkins S. 2015. Role of the insect supervectors Bemisia tabaci and Frankliniella occidentalis in the emergence and global spread of plant viruses. Annual Review of Virology 2:67-93.

Gleadow R, Pegg A, and Blomstedt CK. 2016. Resilience of cassava (Manihot esculenta Crantz) to salinity: implications for food security in low-lying regions. Journal of Experimental Botany 67:5403-5413. $10.1093 / \mathrm{jxb} / \mathrm{erw} 302$

Gómez-Díaz JS, Montoya-Lerma J, and Muñoz-Valencia V. 2019. Prevalence and diversity of endosymbionts in cassava whiteflies (Hemiptera: Aleyrodidae) from Colombia. Journal of Insect Science 19:12. 10.1093/jisesa/iez047

Gutierrez S, and Zwart MP. 2018. Population bottlenecks in multicomponent viruses: first forays into the uncharted territory of genome-formula drift. Current Opinion in Virology 33:184-190. 10.1016/j.coviro.2018.09.001

Hadjistylli M, Roderick GK, and Brown JK. 2016. Global population structure of a worldwide pest and virus vector: Genetic diversity and population history of the Bemisia tabaci sibling species group. PLoS ONE 11:e0165105. 10.1371/journal.pone.0165105

Herrera Campo BV, Hyman G, and Bellotti A. 2011. Threats to cassava production: known and potential geographic distribution of four key biotic constraints. Food Security 3:329.

Hodges GS, and Evans GA. 2005. An iddntification guide to the whiteflies (Hemiptera: Aleyrodidae) of the southeastern United States. Florida Entomologist 88:518-534, 517.

Inoue-Nagata AK, Albuquerque LC, Rocha WB, and Nagata T. 2004. A simple method for cloning the complete begomovirus genome using the bacteriophage phi29 DNA polymerase. Journal of Virological Methods 116:209-211. 10.1016/j.jviromet.2003.11.015

Jacobson AL, Duffy S, and Sseruwagi P. 2018. Whitefly-transmitted viruses threatening cassava production in Africa. Current Opinion in Virology 33:167-176. 10.1016/j.coviro.2018.08.016

Kearse M, Moir R, Wilson A, Stones-Havas S, Cheung M, Sturrock S, Buxton S, Cooper A, Markowitz S, Duran C, Thierer T, Ashton B, Meintjes P, and Drummond A. 2012. Geneious Basic: an integrated and extendable desktop software platform for the organization and analysis of sequence data. Bioinformatics 28:1647-1649. 10.1093/bioinformatics/bts199

Kumar S, Stecher G, and Tamura K. 2016. MEGA7: molecular evolutionary genetics analysis version 7.0 for bigger datasets. Molecular Biology and Evolution 33:1870-1874.

Kunz D, Tay WT, Elfekih S, Gordon KHJ, and De Barro PJ. 2019. Take out the rubbish-Removing NUMTs and pseudogenes from the Bemisia tabaci cryptic species mtCOI database. bioRxiv:724765.

Lee W, Park J, Lee GS, Lee S, and Akimoto SI. 2013. Taxonomic status of the Bemisia tabaci complex (Hemiptera: Aleyrodidae) and reassessment of the number of its constituent species. PLoS ONE 8:e63817.

Lefeuvre P, Martin DP, Harkins G, Lemey P, Gray AJA, Meredith S, Lakay F, Monjane A, Lett JM, Varsani A, and Heydarnejad J. 2010. The spread of tomato yellow leaf curl virus from the Middle East to the world. Plos Pathogens 6:e1001164. 10.1371/journal.ppat.1001164

Legg J, and Fauquet C. 2004. Cassava mosaic geminiviruses in Africa. Plant Molecular Biology 56:585599.

Legg JP, Lava Kumar P, Makeshkumar T, Tripathi L, Ferguson M, Kanju E, Ntawuruhunga P, and Cuellar W. 2015. Cassava virus diseases: Biology, epidemiology, and management. Advances in Virus Research 91:85-142. 10.1016/bs.aivir.2014.10.001

Peer] reviewing PDF | (2021:02:57747:2:0:NEW 4 Jun 2021) 
738

739

740

741

742

743

744

745

746

747

748

749

750

751

752

753

754

755

756

757

758

759

760

761

762

763

764

765

766

767

768

769

770

771

772

773

774

775

776

777

778

779

780

781

782

783

784

785

786

Legg JP, Sseruwagi P, Boniface S, Okao-Okuja G, Shirima R, Bigirimana S, Gashaka G, Herrmann HW, Jeremiah S, Obiero H, Ndyetabula I, Tata-Hangy W, Masembe C, and Brown JK. 2014. Spatiotemporal patterns of genetic change amongst populations of cassava Bemisia tabaci whiteflies driving virus pandemics in East and Central Africa. Virus Research 186:61-75.

Leotard G, Duputie A, Kjellberg F, Douzery EJ, Debain C, de Granville JJ, and McKey D. 2009. Phylogeography and the origin of cassava: new insights from the northern rim of the Amazonian basin. Molecular Phylogenetics and Evolution 53:329-334.

Liu BM, Yan FM, Chu D, Pan HP, Jiao XG, Xie W, Wu QJ, Wang SL, Xu BY, Zhou XG, and Zhang YJ. 2012. Difference in feeding behaviors of two invasive whiteflies on host plants with different suitability: implication for competitive displacement. International Journal of Biological Sciences 8:697-706. 10.7150/ijbs.4108

Luan J-b, Xu J, Lin K-k, Zalucki MP, and Liu S-s. 2012. Species exclusion between an invasive and an indigenous whitefly on host plants with differential levels of suitability. Journal of Integrative Agriculture 11:215-224. https://doi.org/10.1016/S2095-3119(12)60006-9

Mabvakure B, Martin DP, Kraberger S, Cloete L, van Brunschot S, Geering AD, Thomas JE, Bananej K, Lett JM, Lefeuvre P, Varsani A, and Harkins GW. 2016. Ongoing geographical spread of Tomato yellow leaf curl virus. Virology 498:257-264. 10.1016/j.virol.2016.08.033

Macedo MA, Albuquerque LC, Maliano MR, Souza JO, Rojas MR, Inoue-Nagata AK, and Gilbertson RL. 2018. Characterization of tomato leaf curl purple vein virus, a new monopartite New World begomovirus infecting tomato in Northeast Brazil. Archives of Virology 163:737-743. $10.1007 / \mathrm{s} 00705-017-3662-0$

Malka O, Santos-Garcia D, Feldmesser E, Sharon E, Krause-Sakate R, Delatte H, van Brunschot S, Patel M, Visendi P, Mugerwa H, Seal S, Colvin J, and Morin S. 2018. Species-complex diversification and host-plant associations in Bemisia tabaci: A plant-defence, detoxification perspective revealed by RNA-Seq analyses. Molecular Ecology 27:4241-4256.

Mar TB, Mendes IR, Lau D, Fiallo-Olive E, Navas-Castillo J, Alves MS, and Zerbini FM. 2017a. Interaction between the New World begomovirus Euphorbia yellow mosaic virus and its associated alphasatellite: effects on infection and transmission by the whitefly Bemisia tabaci. Journal of General Virology 98:1552-1562. 10.1099/jgv.0.000814

Mar TB, Xavier CAD, Lima ATM, Nogueira AM, Silva JCF, Ramos-Sobrinho R, Lau D, and Zerbini FM. 2017b. Genetic variability and population structure of the New World begomovirus Euphorbia yellow mosaic virus. Journal of General Virology 98:1537-1551. 10.1099/jgv.0.000784

Marubayashi JM, Kliot A, Yuki VA, Rezende JA, Krause-Sakate R, Pavan MA, and Ghanim M. 2014. Diversity and localization of bacterial endosymbionts from whitefly species collected in Brazil. PLoS ONE 9:e108363. 10.1371/journal.pone.0108363

Marubayashi JM, Yuki VA, Rocha KCG, Mituti T, Pelegrinotti FM, Ferreira FZ, Moura MF, NavasCastillo J, Moriones E, Pavan MA, and Krause-Sakate R. 2013. At least two indigenous species of the Bemisia tabaci complex are present in Brazil. Journal of Applied Entomology 137:113-121. 10.1111/j.1439-0418.2012.01714.x

Maruthi MN, Jeremiah SC, Mohammed IU, and Legg JP. 2017. The role of the whitefly, Bemisia tabaci (Gennadius), and farmer practices in the spread of cassava brown streak ipomoviruses. Journal of Phytopathology 165:707-717. 10.1111/jph.12609

Milenovic M, Wosula EN, Rapisarda C, and Legg JP. 2019. Impact of host plant species and whitefly species on feeding behavior of Bemisia tabaci. Frontiers in Plant Science 10:1. 10.3389/fpls.2019.00001

Minato N, Sok S, Chen S, Delaquis E, Phirun I, Le VX, Burra DD, Newby JC, Wyckhuys KAG, and de Haan S. 2019. Surveillance for Sri Lankan cassava mosaic virus (SLCMV) in Cambodia and Vietnam one year after its initial detection in a single plantation in 2015. PLoS ONE 14:e0212780. 10.1371/journal.pone. 0212780

Peer) reviewing PDF | (2021:02:57747:2:0:NEW 4 Jun 2021) 
787

788

789

790

791

792

793

794

795

796

797

798

799

800

801

802

803

804

805

806

807

808

809

810

811

812

813

814

815

816

817

818

819

820

821

822

823

824

825

826

827

828

829

830

831

832

833

834

835

836

837

Montagnac JA, Davis CR, and Tanumihardjo SA. 2009. Nutritional value of cassava for use as a staple food and recent advances for improvement. Comprehensive Reviews in Food Science and Food Safety 8:181-194. 10.1111/j.1541-4337.2009.00077.x

Moraes LA, Marubayashi JM, Yuki VA, Ghanim M, Bello VH, De Marchi BR, Barbosa LF, Boykin LM, Krause-Sakate R, and Pavan MA. 2017. New invasion of Bemisia tabaci Mediterranean species in Brazil associated to ornamental plants. Phytoparasitica 45:517-525.

Moraes LA, Muller C, Bueno R, Santos A, Bello VH, De Marchi BR, Watanabe LFM, Marubayashi JM, Santos BR, Yuki VA, Takada HM, Barros DR, Neves CG, Silva FN, Goncalves MJ, Ghanim M, Boykin L, Pavan MA, and Krause-Sakate R. 2018. Distribution and phylogenetics of whiteflies and their endosymbiont relationships after the Mediterranean species invasion in Brazil. Scientific Reports 8:14589. 10.1038/s41598-018-32913-1

Morris EK, Caruso T, Buscot F, Fischer M, Hancock C, Maier TS, Meiners T, Müller C, Obermaier E, Prati D, Socher SA, Sonnemann I, Wäschke N, Wubet T, Wurst S, and Rillig MC. 2014. Choosing and using diversity indices: insights for ecological applications from the German Biodiversity Exploratories. Ecology and Evolution 4:3514-3524. 10.1002/ece3.1155

Mugerwa H, Seal S, Wang H-L, Patel MV, Kabaalu R, Omongo CA, Alicai T, Tairo F, Ndunguru J, Sseruwagi P, and Colvin J. 2018. African ancestry of New World, Bemisia tabaci-whitefly species. Scientific Reports 8:2734. 10.1038/s41598-018-20956-3

Muhire BM, Varsani A, and Martin DP. 2014. SDT: A virus classification tool based on pairwise sequence alignment and identity calculation. PLoS One 9:e108277.

Nassar N. 2001. Cassava, Manihot esculenta Crantz and wild relatives: their relationships and evolution. Genetic Resources and Crop Evolution 48:429-436. 10.1023/a:1012005008645

Navas-Castillo J, Fiallo-Olivé E, and Sánchez-Campos S. 2011. Emerging virus diseases transmitted by whiteflies. Annual Review of Phytopathology 49:219-248. 10.1146/annurev-phyto-072910-095235

Ndunguru J, Legg J, Aveling T, Thompson G, and Fauquet C. 2005. Molecular biodiversity of cassava begomoviruses in Tanzania: Evolution of cassava geminiviruses in Africa and evidence for East Africa being a center of diversity of cassava geminiviruses. Virology Journal 2:21.

Njoroge MK, Mutisya DL, Miano DW, and Kilalo DC. 2017. Whitefly species efficiency in transmitting cassava mosaic and brown streak virus diseases. Cogent Biology 3:1311499. $10.1080 / 23312025.2017 .1311499$

Nylander JAA. 2004. MrModeltest v2. Program distributed by the author Evolutionary Biology Centre, Uppsala University.

Olsen KM. 2004. SNPs, SSRs and inferences on cassava's origin. Plant Molecular Biology 56:517-526.

Olsen KM, and Schaal BA. 1999. Evidence on the origin of cassava: phylogeography of Manihot esculenta. Proceedings of the National Academy of Sciences, USA 96:5586-5591. 10.1073/pnas.96.10.5586

Pan H, Chu D, Yan W, Su Q, Liu B, Wang S, Wu Q, Xie W, Jiao X, Li R, Yang N, Yang X, Xu B, Brown JK, Zhou X, and Zhang Y. 2012. Rapid spread of tomato yellow leaf curl virus in China is aided differentially by two invasive whiteflies. PLoS ONE 7:e34817. 10.1371/journal.pone.0034817

Pan LL, Cui XY, Chen QF, Wang XW, and Liu SS. 2018. Cotton leaf curl disease: which whitefly is the vector? Phytopathology 108:1172-1183.

Patil BL, and Fauquet CM. 2009. Cassava mosaic geminiviruses: actual knowledge and perspectives. Molecular Plant Pathology 10:685-701.

Paz-Carrasco LC, Castillo-Urquiza GP, Lima AT, Xavier CA, Vivas-Vivas LM, Mizubuti ES, and Zerbini FM. 2014. Begomovirus diversity in tomato crops and weeds in Ecuador and the detection of a recombinant isolate of rhynchosia golden mosaic Yucatan virus infecting tomato. Archives of Virology 159:2127-2132.

Qin L, Pan L-L, and Liu S-S. 2016. Further insight into reproductive incompatibility between putative cryptic species of the Bemisia tabaci whitefly complex. Insect Science 23:215-224. 10.1111/17447917.12296

R Core Team. 2017. R: A language and environment for statistical computing. Available at https://www.Rproject.org/ (accessed 14 Aug 2020.

Peer) reviewing PDF | (2021:02:57747:2:0:NEW 4 Jun 2021) 
838

839

840

841

842

843

844

845

846

847

848

849

850

851

852

853

854

855

856

857

858

859

860

861

862

863

864

865

866

867

868

869

870

871

872

873

874

875

876

877

878

879

880

881

882

883

884

885

886

887

Rey C, and Vanderschuren H. 2017. Cassava mosaic and brown streak diseases: Current perspectives and beyond. Annual Review of Virology 4:429-452. 10.1146/annurev-virology-101416-041913

Ribeiro SG, Ávila AC, Bezerra IC, Fernandes JJ, Faria JC, Lima MF, Gilbertson RL, Zambolim EM, and Zerbini FM. 1998. Widespread occurrence of tomato geminiviruses in Brazil, associated with the new biotype of the whitefly vector. Plant Disease 82:830. 10.1094/PDIS.1998.82.7.830C

Rocha CS, Castillo-Urquiza GP, Lima ATM, Silva FN, Xavier CAD, Hora-Junior BT, Beserra-Junior JEA, Malta AWO, Martin DP, Varsani A, Alfenas-Zerbini P, Mizubuti ESG, and Zerbini FM. 2013. Brazilian begomovirus populations are highly recombinant, rapidly evolving, and segregated based on geographical location. Journal of Virology 87:5784-5799. 10.1128/JVI.00155-13

Rocha KCG, Marubayashi JM, Navas-Castillo J, Yuki VA, Wilcken CF, Pavan MA, and Krause-Sakate R. 2011. Only the B biotype of Bemisia tabaci is present on vegetables in Sao Paulo State, Brazil. Scientia Agricola 68:120-123.

Rodríguez-Negrete EA, Morales-Aguilar JJ, Domínguez-Duran G, Torres-Devora G, Camacho-Beltrán E, Leyva-López NE, Voloudakis AE, Bejarano ER, and Méndez-Lozano J. 2019. High-throughput sequencing reveals differential begomovirus species diversity in non-cultivated plants in NorthernPacific Mexico. Viruses 11:594.

Rojas MR, Gilbertson RL, Russell DR, and Maxwell DP. 1993. Use of degenerate primers in the polymerase chain reaction to detect whitefly-transmitted geminiviruses. Plant Disease 77:340-347.

Ronquist F, and Huelsenbeck JP. 2003. MrBayes 3: Bayesian phylogenetic inference under mixed models. Bioinformatics 19:1572-1574.

Sacristan S, Malpica JM, Fraile A, and Garcia-Arenal F. 2003. Estimation of population bottlenecks during systemic movement of Tobacco mosaic virus in tobacco plants. Journal of Virology 77:9906-9911. 10.1128/jvi.77.18.9906-9911.2003

Sambrook J, and Russel D. 2001. Molecular Cloning - A Laboratory Manual (3 ${ }^{a}$ ed.). Cold Spring Harbor, NY: Cold Spring Harbor Laboratory Press.

Scott IAW, Workman PJ, Drayton GM, and Burnip GM. 2007. First record of Bemisia tabaci biotype Q in New Zealand. New Zealand Plant Protection 60:264-270.

Simon C, Frati F, Beckenbach A, Crespi B, Liu H, and Flook P. 1994. Evolution, weighting and phylogenetic utility of mitochondrial gene sequences and a compilation of conserved polymerase chain reaction primers. Annals of the Entomological Society of America 87:651-701. 10.1093/aesa/87.6.651

Sottoriva LDM, Lourenção AL, and Colombo CA. 2014. Performance of Bemisia tabaci (Genn.) biotype B (Hemiptera: Aleyrodidae) on weeds. Neotropical Entomology 43:574-581. 10.1007/s13744-014$0238-5$

Sun D-B, Liu Y-Q, Qin L, Xu J, Li F-F, and Liu S-S. 2013. Competitive displacement between two invasive whiteflies: insecticide application and host plant effects. Bulletin of Entomological Research 103:344-353. 10.1017/s0007485312000788

Tajebe LS, Boni SB, Guastella D, Cavalieri V, Lund OS, Rugumamu CP, Rapisarda C, and Legg JP. 2015. Abundance, diversity and geographic distribution of cassava mosaic disease pandemic-associated Bemisia tabaci in Tanzania. Journal of Applied Entomology 139:627-637. 10.1111/jen.12197

Tiendrebeogo F, Lefeuvre P, Hoareau M, Harimalala MA, De Bruyn A, Villemot J, Traore VS, Konate G, Traore AS, Barro N, Reynaud B, Traore O, and Lett JM. 2012. Evolution of African cassava mosaic virus by recombination between bipartite and monopartite begomoviruses. Virology Journal 9:67.

Tocko-Marabena BK, Silla S, Simiand C, Zinga I, Legg J, Reynaud B, and Delatte H. 2017. Genetic diversity of Bemisia tabaci species colonizing cassava in Central African Republic characterized by analysis of cytochrome c oxidase subunit I. PLoS ONE 12:e182749.

Vasquez-Ordonez AA, Hazzi NA, Escobar-Prieto D, Paz-Jojoa D, and Parsa S. 2015. A geographic distribution database of the Neotropical cassava whitefly complex (Hemiptera, Aleyrodidae) and their associated parasitoids and hyperparasitoids (Hymenoptera). Zookeys:75-87. 10.3897/zookeys.545.6193

Peer) reviewing PDF | (2021:02:57747:2:0:NEW 4 Jun 2021) 
888

889

890

891

892

893

894

895

896

897

898

899

900

901

902

903

904

905

906

907

908

909

910

911

912

913

914

915

916

917

918

919

920

921

Vyskočilová S, Seal S, and Colvin J. 2019. Relative polyphagy of "Mediterranean" cryptic Bemisia tabaci whitefly species and global pest status implications. Journal of Pest Science 92:1071-1088. 10.1007/s10340-019-01113-9

Vyskočilová S, Tay WT, van Brunschot S, Seal S, and Colvin J. 2018. An integrative approach to discovering cryptic species within the Bemisia tabaci whitefly species complex. Scientific Reports 8:10886. 10.1038/s41598-018-29305-w

Walsh PS, Metzger DA, and Higuchi R. 1991. Chelex 100 as a medium for simple extraction of DNA for PCR-based typing from forensic material. Biotechniques 10:506-513.

Wang D, Huang G, Shi T, Wang G, Fang R, Zhang X, and Ye J. 2020. Surveillance and distribution of the emergent Sri Lankan cassava mosaic virus in China. Phytopathology Research 2:18. 10.1186/s42483-020-00063-w

Wang D, Yao X, Huang G, Shi T, Wang G, and Ye J. 2019. First report of Sri Lankan cassava mosaic virus infected cassava in China. Plant Disease 103:1437.

Wang HL, Cui XY, Wang XW, Liu SS, Zhang ZH, and Zhou XP. 2016. First report of Sri Lankan cassava mosaic virus infecting cassava in Cambodia. Plant Disease 100:1029-1029. 10.1094/pdis-10-151228-pdn

Watanabe LFM, Bello VH, De Marchi BR, Silva FBd, Fusco LM, Sartori MM, Pavan MA, and KrauseSakate R. 2019. Performance and competitive displacement of Bemisia tabaci MEAM1 and MED cryptic species on different host plants. Crop Protection 124:104860. https://doi.org/10.1016/j.cropro.2019.104860

Watling J, Shock MP, Mongeló GZ, Almeida FO, Kater T, De Oliveira PE, and Neves EG. 2018. Direct archaeological evidence for Southwestern Amazonia as an early plant domestication and food production centre. PLOS ONE 13:e0199868. 10.1371/journal.pone.0199868

Whitfield AE, Falk BW, and Rotenberg D. 2015. Insect vector-mediated transmission of plant viruses. Virology 480:278-289.

Wilson AK. 1981. Euphorbia heterophylla: A review of distribution, importance and control. Tropical Pest Management 27:32-38.

Zerbini FM, Briddon RW, Idris A, Martin DP, Moriones E, Navas-Castillo J, Rivera-Bustamante R, Varsani A, and ICTV Consortium. 2017. ICTV Virus Taxonomy Profile: Geminiviridae. Journal of General Virology 98:131-133. 10.1099/jgv.0.000738

Zhou X, Liu Y, Calvert L, Munoz C, Otim-Nape GW, Robinson DJ, and Harrison BD. 1997. Evidence that DNA-A of a geminivirus associated with severe cassava mosaic disease in Uganda has arisen by interspecific recombination. Journal of General Virology 78:2101-2111.

PeerJ reviewing PDF | (2021:02:57747:2:0:NEW 4 Jun 2021) 


\section{Table $\mathbf{1}$ (on next page)}

Sampled sites and whiteflies species detected in cassava in Brazil 
1 Table 1. Sampled sites and whiteflies species detected in cassava in Brazil.

\begin{tabular}{|c|c|c|c|c|c|c|c|c|c|c|c|}
\hline \multirow[t]{2}{*}{ Sample } & \multirow{2}{*}{$\begin{array}{l}\text { Date of } \\
\text { collection }\end{array}$} & \multirow[t]{2}{*}{ Location } & \multirow[t]{2}{*}{ Region } & \multicolumn{2}{|c|}{ Geographical coordinates } & \multirow[t]{2}{*}{ Alt. } & \multicolumn{3}{|c|}{ Number of samples } & \multirow[t]{2}{*}{ Whiteflies species $^{c}$} & \multirow[t]{2}{*}{ Reference } \\
\hline & & & & Latitude & Longitude & & $\mathbf{A d}^{\mathrm{b}}$ & $\mathbf{N y}$ & $\mathbf{T}$ & & \\
\hline AL1 & July 2018 & Arapiraca, $\mathrm{AL}^{\mathrm{a}}$ & Northeast & $09^{\circ} 48^{\prime} 27.66^{\prime \prime S}$ & $36^{\circ} 36^{\prime} 40.68^{\prime \prime} \mathrm{W}$ & 241 & 15 & 15 & 30 & Btu, Ta & This study \\
\hline AL2 & April 2018 & TeotonioVilela, AL & Northeast & $09^{\circ} 53^{\prime} 16.86^{\prime \prime S}$ & $36^{\circ} 23^{\prime} 05.52^{\prime \prime} \mathrm{W}$ & 167 & 15 & 15 & 30 & BtM, BtNW, Btu, Ta & This study \\
\hline AL3 & April 2018 & União dos Palmares, AL & Northeast & $09^{\circ} 11^{\prime} 51.84 " \mathrm{~S}$ & $36^{\circ} 01 " 51.90 " \mathrm{~W}$ & 154 & 14 & 10 & 24 & BtM, BtNW, Btu, Ta & This study \\
\hline AL4 & April 2018 & Arapiraca, AL & Northeast & $09^{\circ} 47^{\prime} 29.46 " \mathrm{~S}$ & $36^{\circ} 25^{\prime} 36.00^{\prime \prime} \mathrm{W}$ & 143 & 14 & 15 & 29 & BtM, Btu, Ta & This study \\
\hline AL5 & April 2018 & Arapiraca, AL & Northeast & $09^{\circ} 43^{\prime} 09.30^{\prime \prime} \mathrm{S}$ & $36^{\circ} 40^{\prime} 45.60^{\prime \prime} \mathrm{W}$ & 298 & 16 & 15 & 31 & $\mathrm{BtM}, \mathrm{Ta}$ & This study \\
\hline BA1 & December 2017 & Barra, BA & Northeast & $11^{\circ} 20^{\prime} 52.37 " \mathrm{~S}$ & $43^{\circ} 12^{\prime} 57.44^{\prime \prime} \mathrm{W}$ & 409 & 28 & 0 & 28 & BtM, Btu, Ta & This study \\
\hline BA2 & March 2018 & $\begin{array}{l}\text { Luis Eduardo Magalhães, } \\
\text { BA }\end{array}$ & Northeast & $12^{\circ} 20^{\prime} 10.00^{\prime \prime S}$ & $45^{\circ} 49^{\prime} 12.00^{\prime \prime} \mathrm{W}$ & 744 & 10 & 10 & 20 & BtM, Btu & This study \\
\hline BA3 & June 2018 & Wanderley, BA & Northeast & $12^{\circ} 13^{\prime} 42.04^{\prime \prime S}$ & $43^{\circ} 55^{\prime} 50.00^{\prime \prime} \mathrm{W}$ & 875 & 14 & 0 & 14 & BtM, Ta & This study \\
\hline BA4 & March 2018 & Cristópolis, BA & Northeast & $12^{\circ} 13^{\prime} 56.08^{\prime \prime S}$ & $44^{\circ} 23^{\prime} 11.50^{\prime \prime} \mathrm{W}$ & 694 & 13 & 0 & 13 & BtM, Ta & This study \\
\hline DF1 & March 2018 & Planaltina, DF & Midwest & $15^{\circ} 30^{\prime} 59.00^{\prime \prime} \mathrm{S}$ & $47^{\circ} 16^{\prime} 09.00^{\prime \prime} \mathrm{W}$ & 809 & 10 & 0 & 10 & $\mathrm{BtM}$ & This study \\
\hline DF2 & March 2018 & Planaltina, DF & Midwest & $15^{\circ} 28^{\prime} 57.00^{\prime \prime} \mathrm{S}$ & $47^{\circ} 20^{\prime} 06.00^{\prime \prime} \mathrm{W}$ & 757 & 10 & 0 & 10 & BtM & This study \\
\hline DF3 & March 2018 & Planaltina, DF & Midwest & $15^{\circ} 31^{\prime} 17.00^{\prime \prime S}$ & $47^{\circ} 21^{\prime} 22.00^{\prime \prime} \mathrm{W}$ & 874 & 10 & 0 & 10 & BtM & This study \\
\hline $\mathrm{ES} 1$ & January 2018 & Sooretama, ES & Southeast & $19^{\circ} 06^{\prime} 52.02^{\prime \prime S}$ & $40^{\circ} 04^{\prime} 46.30^{\prime \prime} \mathrm{W}$ & 60 & 11 & 11 & 22 & $\mathrm{Ta}$ & This study \\
\hline ES2 & January 2018 & Marilândia, ES & Southeast & $19^{\circ} 24^{\prime} 22.04^{\prime \prime S}$ & $40^{\circ} 32^{\prime} 21.70^{\prime \prime} \mathrm{W}$ & 111 & 14 & 15 & 29 & $\mathrm{BtM}, \mathrm{Ta}$ & This study \\
\hline ES3 & January 2018 & Pinheiros, ES & Southeast & $18^{\circ} 40^{\prime} 83.20^{\prime \prime} \mathrm{S}$ & $40^{\circ} 28^{\prime} 63.40^{\prime \prime} \mathrm{W}$ & 88 & 15 & 15 & 30 & BtM, Btu, Ta & This study \\
\hline GO1 & March 2018 & Bela Vista, GO & Midwest & $16^{\circ} 59^{\prime} 50.00^{\prime \prime S}$ & $48^{\circ} 57^{\prime} 56.00^{\prime \prime} \mathrm{W}$ & 808 & 10 & 11 & 21 & BtM & This study \\
\hline GO2 & March 2018 & Itaberaí, GO & Midwest & $15^{\circ} 56^{\prime} 58.00^{\prime \prime} \mathrm{S}$ & $49^{\circ} 47^{\prime} 07.00^{\prime \prime} \mathrm{W}$ & 765 & 15 & 15 & 30 & BtM, Btu & This study \\
\hline MG1 & February 2018 & Ouro Fino, $\mathrm{MG}$ & Southeast & $22^{\circ} 16^{\prime} 44.00^{\prime \prime} \mathrm{S}$ & $46^{\circ} 29^{\prime} 33.00^{\prime \prime} \mathrm{W}$ & 846 & 10 & 10 & 20 & $\mathrm{Ta}$ & This study \\
\hline MG2 & February 2018 & Pouso Alegre, MG & Southeast & $22^{\circ} 15^{\prime} 01.00^{\prime \prime S}$ & $46^{\circ} 58^{\prime} 31.00^{\prime \prime} \mathrm{W}$ & 677 & 15 & 15 & 30 & BtM, Btu, Ta & This study \\
\hline MG3 & February 2018 & Careaçu, MG & Southeast & $22^{\circ} 04^{\prime} 37.00^{\prime \prime} \mathrm{S}$ & $45^{\circ} 41^{\prime} 49.00^{\prime \prime} \mathrm{W}$ & 813 & 15 & 15 & 30 & Btu, Ta & This study \\
\hline MG4 & February 2018 & Lambari, $\mathrm{MG}$ & Southeast & $21^{\circ} 56^{\prime} 05.00^{\prime \prime} \mathrm{S}$ & $45^{\circ} 15^{\prime} 49.00^{\prime \prime} \mathrm{W}$ & 864 & 15 & 15 & 30 & BtM, Ta & This study \\
\hline MG5 & February 2018 & Lima Duarte, $\mathrm{MG}$ & Southeast & $21^{\circ} 50^{\prime} 35.00^{\prime \prime} \mathrm{S}$ & $43^{\circ} 47^{\prime} 01.00^{\prime \prime} \mathrm{W}$ & 751 & 11 & 11 & 22 & $\mathrm{Ta}$ & This study \\
\hline MG6 & February 2018 & RioPomba, MG & Southeast & $21^{\circ} 15^{\prime} 50.00^{\prime \prime} \mathrm{S}$ & $43^{\circ} 09^{\prime} 59.00^{\prime \prime} \mathrm{W}$ & 504 & 15 & 15 & 30 & Btu, WtNEW2 & This study \\
\hline MG7 & March 2018 & Florestal, MG & Southeast & $19^{\circ} 54^{\prime} 13.00^{\prime \prime S}$ & $44^{\circ} 25^{\prime} 48.00^{\prime \prime} \mathrm{W}$ & 793 & 10 & 10 & 20 & $\mathrm{Ta}$ & This study \\
\hline MG8 & March 2018 & Florestal, MG & Southeast & $19^{\circ} 51^{\prime} 20.00^{\prime \prime S}$ & $44^{\circ} 23^{\prime} 58.00^{\prime \prime} \mathrm{W}$ & 704 & 10 & 10 & 20 & $\mathrm{Ta}$ & This study \\
\hline MG9 & March 2018 & Florestal, MG & Southeast & $19^{\circ} 53^{\prime} 39.00^{\prime \prime S}$ & $44^{\circ} 24^{\prime} 55.00^{\prime \prime} \mathrm{W}$ & 769 & 15 & 15 & 30 & $\mathrm{BtM}, \mathrm{Ta}$ & This study \\
\hline MG10 & March 2018 & Florestal, MG & Southeast & $19^{\circ} 52^{\prime} 38.00^{\prime \prime} \mathrm{S}$ & $44^{\circ} 25^{\prime} 21.00^{\prime \prime} \mathrm{W}$ & 780 & 16 & 13 & 29 & BtM, Btu, Ta & This study \\
\hline
\end{tabular}




\begin{tabular}{|c|c|c|c|c|c|c|c|c|c|c|c|}
\hline MG11 & March 2018 & Florestal, MG & Southeast & $19^{\circ} 52^{\prime} 38.00^{\prime \prime S}$ & $44^{\circ} 25^{\prime} 21.00^{\prime \prime} \mathrm{W}$ & 780 & 15 & 14 & 29 & $\mathrm{Ta}$ & This study \\
\hline MG12 & March 2018 & Divinópolis, $\mathrm{MG}$ & Southeast & $20^{\circ} 06^{\prime} 21.00^{\prime \prime S}$ & $44^{\circ} 55^{\prime} 36.00^{\prime \prime} \mathrm{W}$ & 782 & 15 & 15 & 30 & Btu, Ta & This study \\
\hline MG13 & March 2018 & Viçosa, MG & Southeast & $20^{\circ} 46^{\prime} 06.00^{\prime \prime} \mathrm{S}$ & $42^{\circ} 52^{\prime} 14.00^{\prime \prime} \mathrm{W}$ & 661 & 14 & 11 & 25 & $\begin{array}{l}\text { BtM, BtNW, Btu, } \\
\text { Ta }\end{array}$ & This study \\
\hline MG14 & April 2018 & Piraúba, MG & Southeast & $21^{\circ} 16^{\prime} 22.71 " \mathrm{~S}$ & $43^{\circ} 02^{\prime} 31.28^{\prime \prime} \mathrm{W}$ & 366 & 10 & 0 & 10 & $\mathrm{Ta}$ & This study \\
\hline MG15 & May 2018 & Descoberto, MG & Southeast & $21^{\circ} 28^{\prime} 06.28^{\prime \prime} \mathrm{S}$ & $42^{\circ} 58^{\prime} 05.53^{\prime \prime} \mathrm{W}$ & 351 & 15 & 15 & 30 & Btu, Ta & This study \\
\hline MG16 & June 2018 & Mar de Espanha, MG & Southeast & $21^{\circ} 46^{\prime} 07.26^{\prime \prime} \mathrm{S}$ & $43^{\circ} 04^{\prime} 26.62^{\prime \prime} \mathrm{W}$ & 508 & 15 & 15 & 30 & Btu, Ta & This study \\
\hline MG17 & July 2018 & Leopoldina, MG & Southeast & $21^{\circ} 33^{\prime} 50.15^{\prime \prime S}$ & $42^{\circ} 40^{\prime} 42.97^{\prime \prime} \mathrm{W}$ & 254 & 9 & 0 & 9 & $\mathrm{Ta}$ & This study \\
\hline MG18 & August 2018 & Dona Euzébia, MG & Southeast & $21^{\circ} 19^{\prime} 18.83 " \mathrm{~S}$ & $42^{\circ} 48^{\prime} 37.07^{\prime \prime} \mathrm{W}$ & 246 & 17 & 0 & 17 & Btu, Ta & This study \\
\hline MG19 & May 2018 & Caparaó, MG & Midwest & $20^{\circ} 31^{\prime} 48.00^{\prime \prime} \mathrm{S}$ & $41^{\circ} 54^{\prime} 00.36^{\prime \prime} \mathrm{W}$ & 864 & 12 & 10 & 22 & $\mathrm{Ta}$ & This study \\
\hline MT1 & December 2017 & Canarana, MT & Midwest & $13^{\circ} 31^{\prime} 16.00^{\prime \prime S}$ & $52^{\circ} 25^{\prime} 03.00^{\prime \prime} \mathrm{W}$ & 312 & 15 & 16 & 31 & WtNEW1 & This study \\
\hline MT2 & December 2017 & Canarana, MT & Midwest & $13^{\circ} 33^{\prime} 47.00^{\prime \prime} \mathrm{S}$ & $52^{\circ} 15^{\prime} 53.00^{\prime \prime} \mathrm{W}$ & 415 & 0 & 20 & 20 & Btu & This study \\
\hline MT4 & January 2018 & Pedra Preta, MT & Midwest & $16^{\circ} 38^{\prime} 29.00^{\prime \prime S}$ & $54^{\circ} 25^{\prime} 41.00^{\prime \prime} \mathrm{W}$ & 241 & 10 & 10 & 20 & Btu & This study \\
\hline MT5 & January 2018 & Pedra Preta, MT & Midwest & $16^{\circ} 39^{\prime} 07.00^{\prime \prime S}$ & $54^{\circ} 22^{\prime} 27.00^{\prime \prime} \mathrm{W}$ & 255 & 10 & 10 & 20 & BtM, Btu & This study \\
\hline MT6 & January 2018 & Pedra Preta, MT & Midwest & $16^{\circ} 39^{\prime} 28.00^{\prime \prime} \mathrm{S}$ & $54^{\circ} 20^{\prime} 20.00^{\prime \prime} \mathrm{W}$ & 303 & 10 & 10 & 20 & BtM, Btu & This study \\
\hline PA1 & January 2018 & Brasil Novo, PA & North & $03^{\circ} 12^{\prime} 23.07^{\prime \prime S}$ & $52^{\circ} 30^{\prime} 13.80^{\prime \prime} \mathrm{W}$ & 170 & 11 & 10 & 21 & $\mathrm{Ta}$ & This study \\
\hline PA2 & January 2018 & Vitória doXingu, PA & North & $03^{\circ} 04^{\prime} 51.01 " \mathrm{~S}$ & $52^{\circ} 10^{\prime} 08.80^{\prime \prime} \mathrm{W}$ & 130 & 10 & 12 & 22 & $\mathrm{Ta}$ & This study \\
\hline PA3 & January 2018 & Altamira, PA & North & $03^{\circ} 18^{\prime} 15.03^{\prime \prime S}$ & $52^{\circ} 07^{\prime} 26.00^{\prime \prime} \mathrm{W}$ & 176 & 15 & 15 & 30 & Btu, Ta & This study \\
\hline PA4 & January 2018 & Altamira, PA & North & $03^{\circ} 09^{\prime} 14.60^{\prime \prime S}$ & $52^{\circ} 07^{\prime} 49.00^{\prime \prime} \mathrm{W}$ & 128 & 15 & 16 & 31 & Btu, Ta & This study \\
\hline PA5 & August 2018 & Belém, PA & North & $01^{\circ} 18^{\prime} 20.00^{\prime \prime S}$ & $48^{\circ} 26^{\prime} 46.00^{\prime \prime} \mathrm{W}$ & 46 & 10 & 10 & 20 & BtM & This study \\
\hline PI1 & April 2018 & Picos, PI & Northeast & $07^{\circ} 04^{\prime} 79.50^{\prime \prime S}$ & $41^{\circ} 25^{\prime} 57.80^{\prime \prime} \mathrm{W}$ & 214 & 0 & 29 & 29 & Btu, Ta & This study \\
\hline PI2 & May 2018 & Teresina, PI & Northeast & $05^{\circ} 02^{\prime} 41.94 " \mathrm{~S}$ & $42^{\circ} 47^{\prime} 18.84^{\prime \prime} \mathrm{W}$ & 71 & 0 & 27 & 27 & Btu, Ta & This study \\
\hline PR1 & March 2018 & $\begin{array}{l}\text { Santo Antôniodo Caiuá, } \\
\text { PR }\end{array}$ & South & $22^{\circ} 41^{\prime} 07.00^{\prime \prime} \mathrm{S}$ & $52^{\circ} 19^{\prime} 06.00^{\prime \prime} \mathrm{W}$ & 342 & 30 & 0 & 30 & Btu, Ta & This study \\
\hline PR2 & March 2018 & $\begin{array}{l}\text { Santo Antôniodo Caiuá, } \\
\text { PR }\end{array}$ & South & $22^{\circ} 49^{\prime} 03.00^{\prime \prime} \mathrm{S}$ & $52^{\circ} 21^{\prime} 25.00^{\prime \prime} \mathrm{W}$ & 439 & 30 & 0 & 30 & BtM, Btu & This study \\
\hline PR3 & March 2018 & Paranavaí, PR & South & $23^{\circ} 06^{\prime} 03.29 " \mathrm{~S}$ & $52^{\circ} 29^{\prime} 10.00^{\prime \prime} \mathrm{W}$ & 471 & 26 & 0 & 26 & Btu, Ta & This study \\
\hline PR4 & March 2018 & Sertanópolis, PR & South & $23^{\circ} 02^{\prime} 54.00^{\prime \prime} \mathrm{S}$ & $50^{\circ} 59^{\prime} 54.00^{\prime \prime} \mathrm{W}$ & 343 & 10 & 10 & 20 & BtM, BtMED & This study \\
\hline $\mathrm{SC} 2$ & March 2018 & Agrônomica, SC & South & $27^{\circ} 34^{\prime} 40.00 " \mathrm{~S}$ & $48^{\circ} 32^{\prime} 08.00^{\prime \prime} \mathrm{W}$ & 34 & 10 & 0 & 10 & BtM & This study \\
\hline SP1 & July 2016 & Holambra, SP & Southeast & $22^{\circ} 36^{\prime} 26.00^{\prime \prime} \mathrm{S}$ & $47^{\circ} 02^{\prime} 50.00^{\prime \prime} \mathrm{W}$ & 634 & 10 & 0 & 10 & BtMED & Moraes et al., 2018 \\
\hline SP2 & July 2016 & Mogi Mirim, SP & Southeast & $22^{\circ} 28^{\prime} 08.00^{\prime \prime S}$ & $46^{\circ} 56^{\prime} 25.00^{\prime \prime} \mathrm{W}$ & 652 & 10 & 0 & 10 & Btu & Moraes et al., 2018 \\
\hline SP3 & July 2016 & Mogi Mirim, SP & Southeast & $22^{\circ} 24^{\prime} 59.00^{\prime \prime} \mathrm{S}$ & $46^{\circ} 59^{\prime} 19.00^{\prime \prime} \mathrm{W}$ & 678 & 10 & 0 & 10 & Btu & Moraes et al., 2018 \\
\hline SP4 & July 2016 & Mogi Mirim, SP & Southeast & $22^{\circ} 26^{\prime} 44.00^{\prime \prime S}$ & $47^{\circ} 04^{\prime} 11.00^{\prime \prime} \mathrm{W}$ & 689 & 10 & 0 & 10 & Btu & Moraes et al., 2018 \\
\hline
\end{tabular}




\begin{tabular}{|c|c|c|c|c|c|c|c|c|c|c|c|}
\hline SP5 & July 2016 & Mogi Mirim, SP & Southeast & $22^{\circ} 27^{\prime} 05.00^{\prime \prime S}$ & $47^{\circ} 04^{\prime} 56.00^{\prime \prime} \mathrm{W}$ & 710 & 10 & 0 & 10 & Btu & Moraes et al., 2018 \\
\hline SP6 & July 2016 & SãoPedro, SP & Southeast & $22^{\circ} 34^{\prime} 08.00^{\prime \prime} \mathrm{S}$ & $48^{\circ} 05^{\prime} 22.00^{\prime \prime} \mathrm{W}$ & 525 & 10 & 0 & 10 & Btu & Moraes et al., 2018 \\
\hline SP7 & July 2017 & Montalvao, SP & Southeast & $22^{\circ} 02^{\prime} 23.00 " \mathrm{~S}$ & $51^{\circ} 19^{\prime} 53.00^{\prime \prime} \mathrm{W}$ & 404 & 10 & 0 & 10 & Btu & Moraes et al., 2018 \\
\hline SP8 & July 2017 & Pindamonhangaba, SP & Southeast & $22^{\circ} 56^{\prime} 05.00^{\prime \prime} \mathrm{S}$ & $45^{\circ} 26^{\prime} 25.00^{\prime \prime} \mathrm{W}$ & 562 & 10 & 0 & 10 & BtM & Moraes et al., 2018 \\
\hline SP9 & March 2016 & Casa Branca, SP & Southeast & $21^{\circ} 11^{\prime} 32.00^{\prime \prime S}$ & $47^{\circ} 48^{\prime} 44.00^{\prime \prime} \mathrm{W}$ & 598 & 10 & 0 & 10 & BtM & Moraes et al., 2018 \\
\hline SP10 & January 2019 & São Pedro do Turvo, SP & Southeast & $22^{\circ} 36^{\prime} 32.00^{\prime \prime S}$ & $49^{\circ} 45^{\prime} 29.00^{\prime \prime} \mathrm{W}$ & 563 & 4 & 10 & 14 & BtM, Btu, BtMED & This study \\
\hline SP11 & January 2019 & Oleo, SP & Southeast & $22^{\circ} 56^{\prime} 32.00^{\prime \prime} \mathrm{S}$ & $49^{\circ} 26^{\prime} 15.00^{\prime \prime} \mathrm{W}$ & 584 & 10 & 0 & 10 & BtMED & This study \\
\hline SP12 & February 2019 & Mogi Mirim, SP & Southeast & $22^{\circ} 28^{\prime} 32.30^{\prime \prime} \mathrm{S}$ & $47^{\circ} 00^{\prime} 47.60^{\prime \prime} \mathrm{W}$ & 675 & 5 & 5 & 10 & Btu & This study \\
\hline SP13 & July 2016 & Casa Branca, SP & Southeast & $21^{\circ} 49^{\prime} 08.00^{\prime \prime} \mathrm{S}$ & $45^{\circ} 58^{\prime} 23.00^{\prime \prime} \mathrm{W}$ & 612 & 10 & 0 & 10 & Btu & Moraes et al., 2018 \\
\hline
\end{tabular}

2 a Brazilian states where samples were collected: AL, Alagoas; BA, Bahia; DF, Distrito Federal; ES, Espírito Santo; GO, Góias; MG, Minas Gerais; MT, Mato

3 Grosso; PA, Pará; PI, Piauí; PR, Paraná; SC, Santa Catarina; SP, São Paulo.

$4 \quad$ b Ad, Adults; Ny, Nymphs; T, Total.

5 ' Btu, Bemisia tuberculata; BtM, Bemisia tabaci MEAM1; BtMED, B. tabaci MED; BtNW, B. tabaci New World; Ta, Tetraleuroides acaciae; WtNEW1,

6 whitefly new species 1 ; WtNEW2, whitefly new species 2 . 


\section{Figure 1}

Overview of the survey locations and whitefly species detected

Figure 1. (A) Clockwise from top-left: Adults and nymphs of Bemisia tuberculata colonizing cassava in Mogi Mirim, São Paulo state. Growth of sooty mould fungus on the leaf surface due to the deposition of honeydew by whiteflies. Presence of begomovirus-infected Blainvillea rhomboidea (family Asteraceae) in a cassava field in Minas Gerais state. Presence of begomovirus-infected Euphorbia heterophylla (family Euphorbiaceae) in a cassava field in Minas Gerais state. (B) Map of Brazil showing the locations where whiteflies samples were collected. The map is colored according to the regions as indicated in the legend. Blacks dots correspond to the sampled sites. Scale bar is only for Brazil map. (C) Number of adults and nymphs analyzed from each sampled site according to state. (D) Specie distribution according to region. AL, Alagoas; BA, Bahia; DF, Distrito Federal; ES, Espírito Santo; GO, Goiás; MG, Minas Gerais; MT, Mato Grosso; PA, Pará; Piauí; PR, Paraná; SC, Santa Catarina; SP, São Paulo. 
A
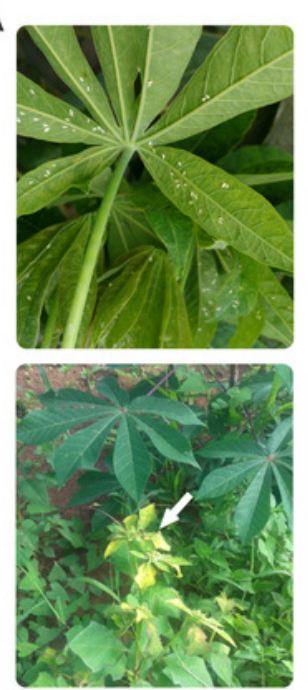

C

Adults Nymphs

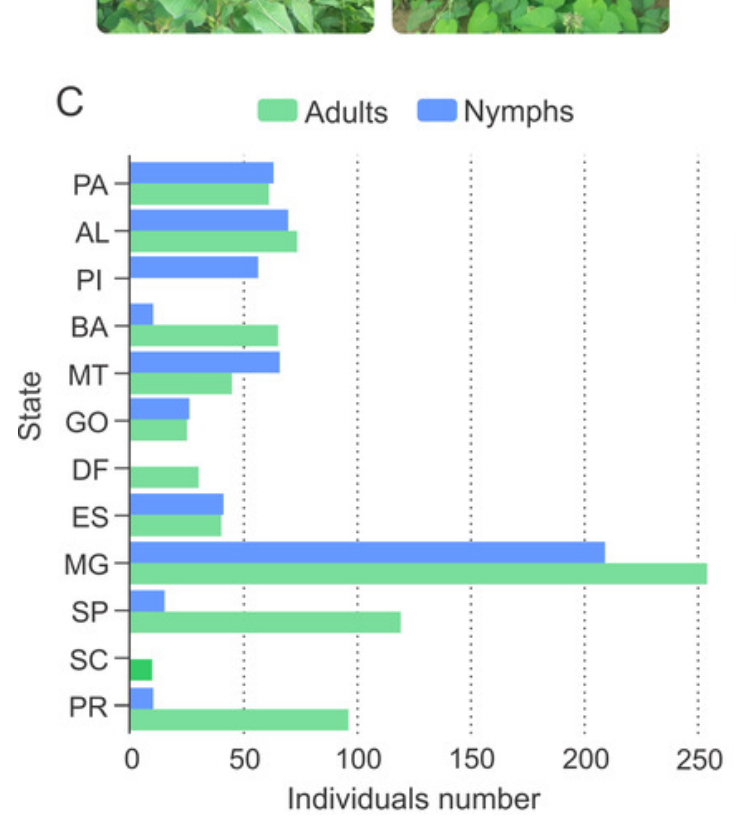

B
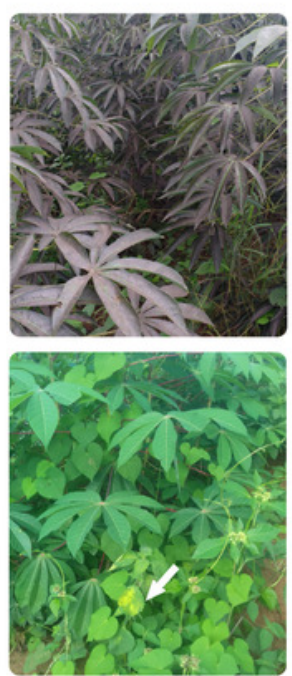

$B$

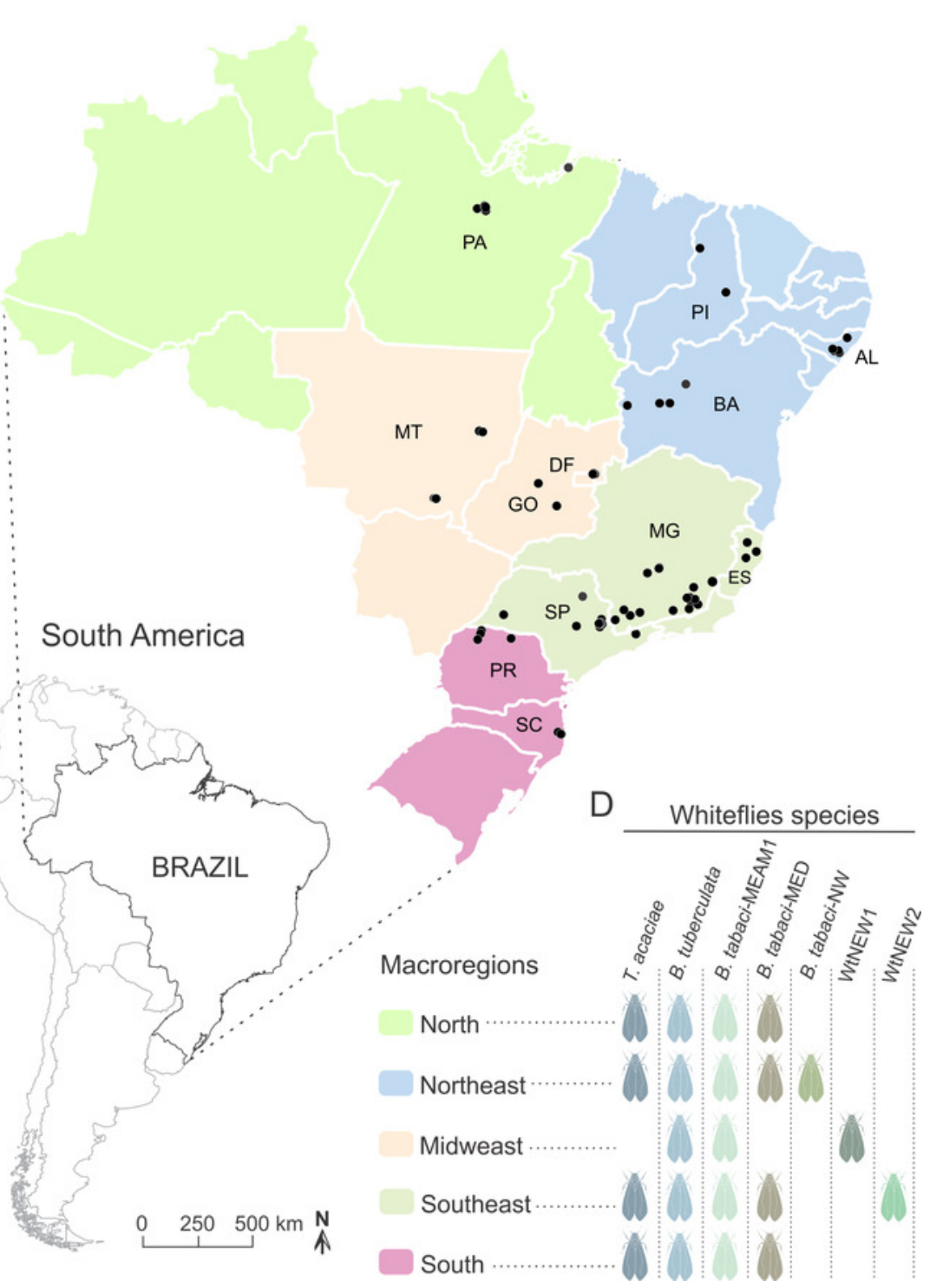




\section{Figure 2}

Phylogenetic relationships among whitely species, including the ones detected in cassava in Brazil, based on the sequence of the $\mathrm{mtCO}$ gene

Figure 2. Bayesian phylogenetic tree based on partial nucleotide sequences of the mitochondrial cytochrome oxidase (mtCOI) gene of representative individuals of each whitefly species detected in this study and reference sequences retrieved from GenBank. The tree was rooted with the aphid Aphis gossypii. Bayesian posterior probabilities are shown at the nodes. The scale bar represents the number of nucleotide substitutions per site. Nodes with posterior probability values between 0.60 and 0.80 are indicated by empty circles and nodes with values equal to or greater than 0.81 are indicated by filled circles. Clades highlighted with different colors indicate the species detected in this study. Branches highlighted in red indicate the putative new species detected here. 


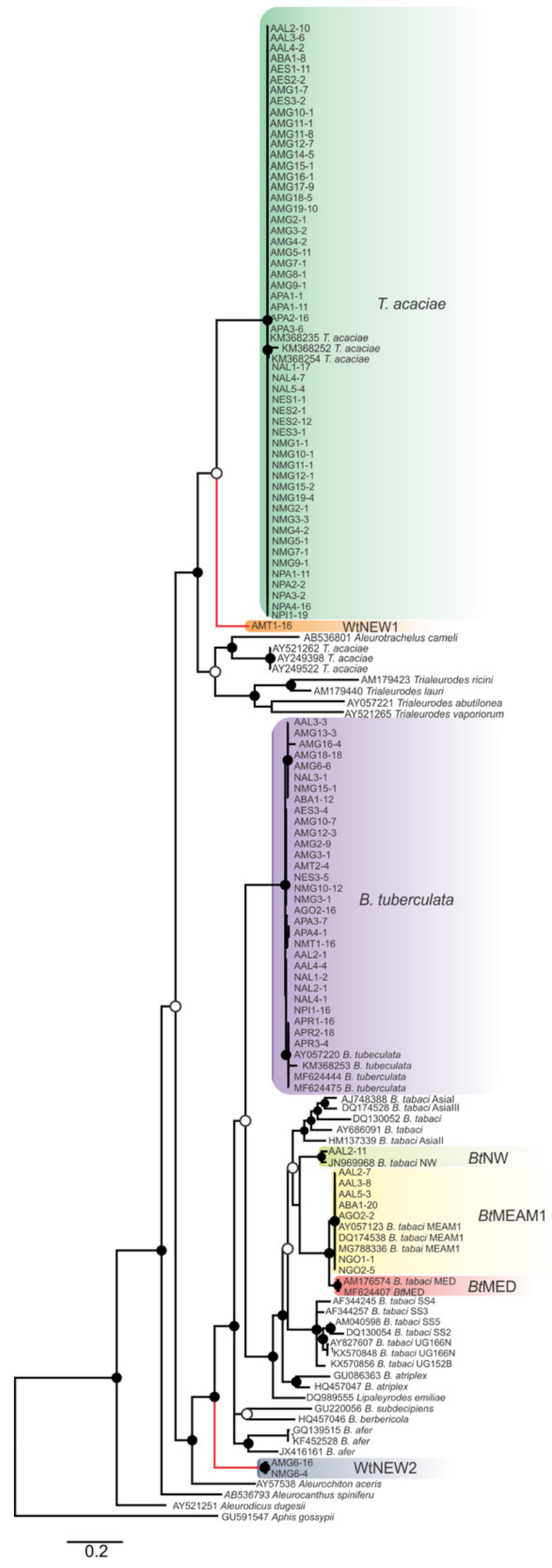

PeerJ reviewing PDF | (2021:02:57747:2:0:NEW 4 Jun 2021) 


\section{Figure 3}

Composition of whitefly populations colonizing cassava in Brazil

Figure 3. Composition of whitefly populations colonizing cassava in Brazil. (A) Species composition at each sampled site according to stage of development (adult and nymphs). Asterisks indicate that nymphs were not detected. (B, C, D) Species distribution of the 1,385 individuals genotyped in this study considering the samples from all sites (B) or only samples from sites where both adults and nymphs were sampled $\mathbf{( C )}$ or without samples from Minas Gerais state (D).

A

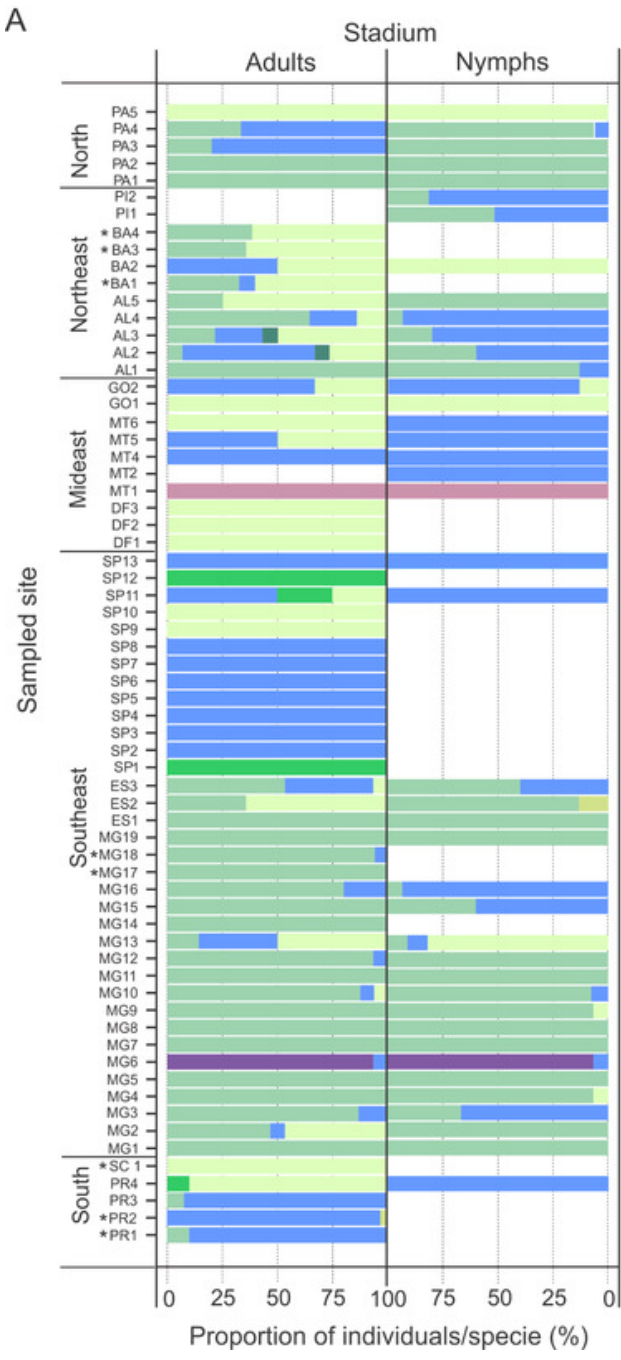

B
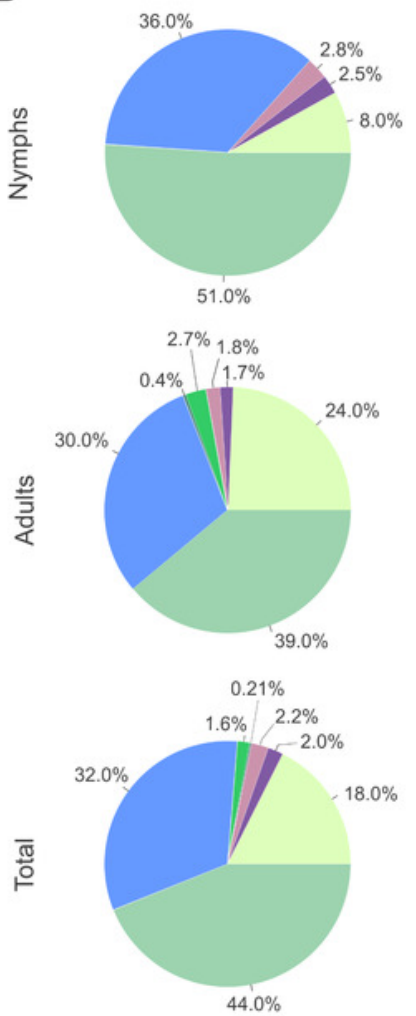

C

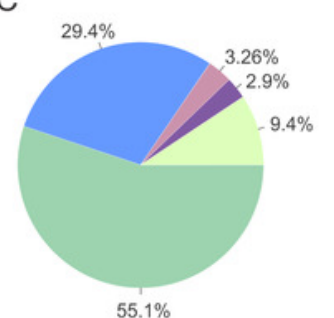

$55.1 \%$
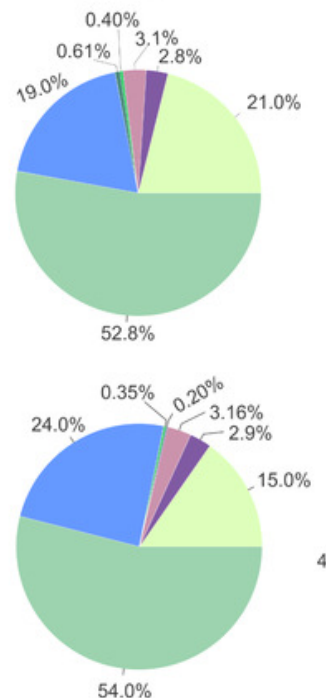
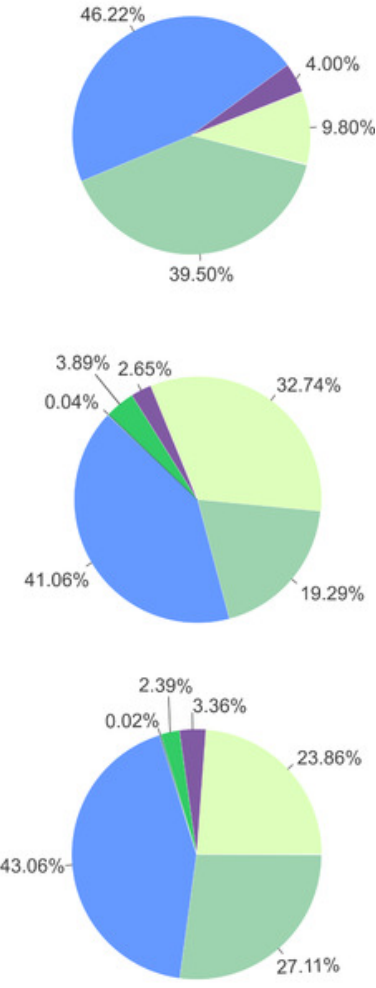

Tetraleurodes acaciae

Bemisia tabaci MED

Bemisia tuberculata

Bemisia tabaci NW

Bemisia tabaci MEAM1

WtNEW1

WtNEW2 


\section{Figure 4}

Incidence of Trialeurodes acaciae, Bemisia tuberculata and B. tabaci MEAM1 in cassava fields in Brazil

Figure 4. (A) Incidence of Trialeurodes acaciae, Bemisia tuberculata and B. tabaci MEAM1 in cassava fields in Brazil, measured as the percentage of sampled sites where at least one individual belonging to each one of the three species was detected. Other species detected at low incidence are shown together as "others". (B) Venn diagram showing the proportion of sites where each one of the three whitefly species occur alone or in different combinations. (C) Competitive capacity inferred based on the prevalence of individuals from each of two species in fields where those two species were detected co-occurring. The horizontal line inside the box corresponds to the median. The asterisk indicates a significant difference according to the non-parametric Kruskal-Wallis test $(p<0.05)$. 
A

B

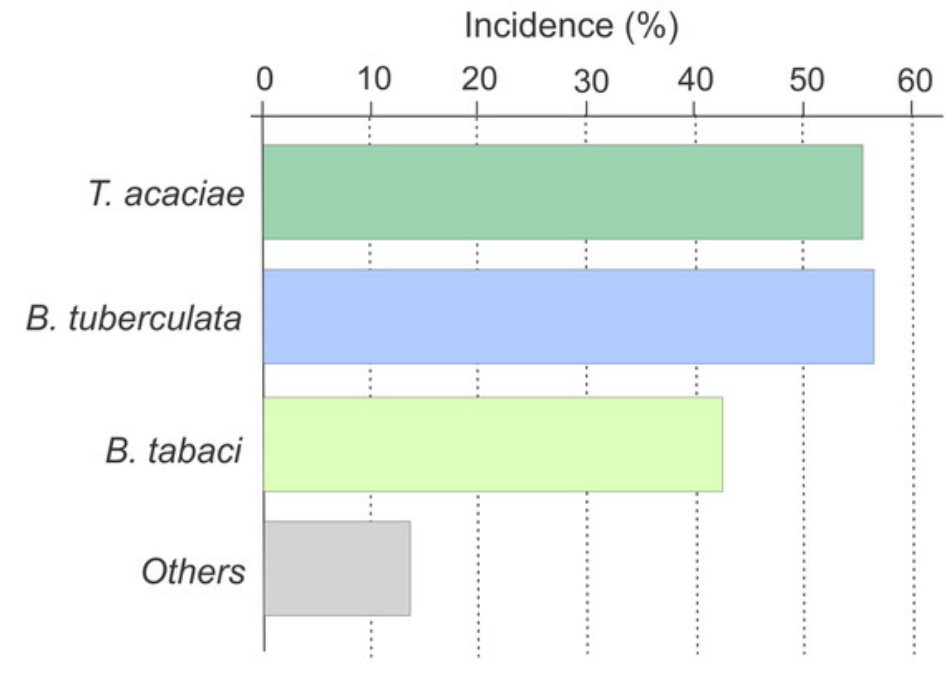

C
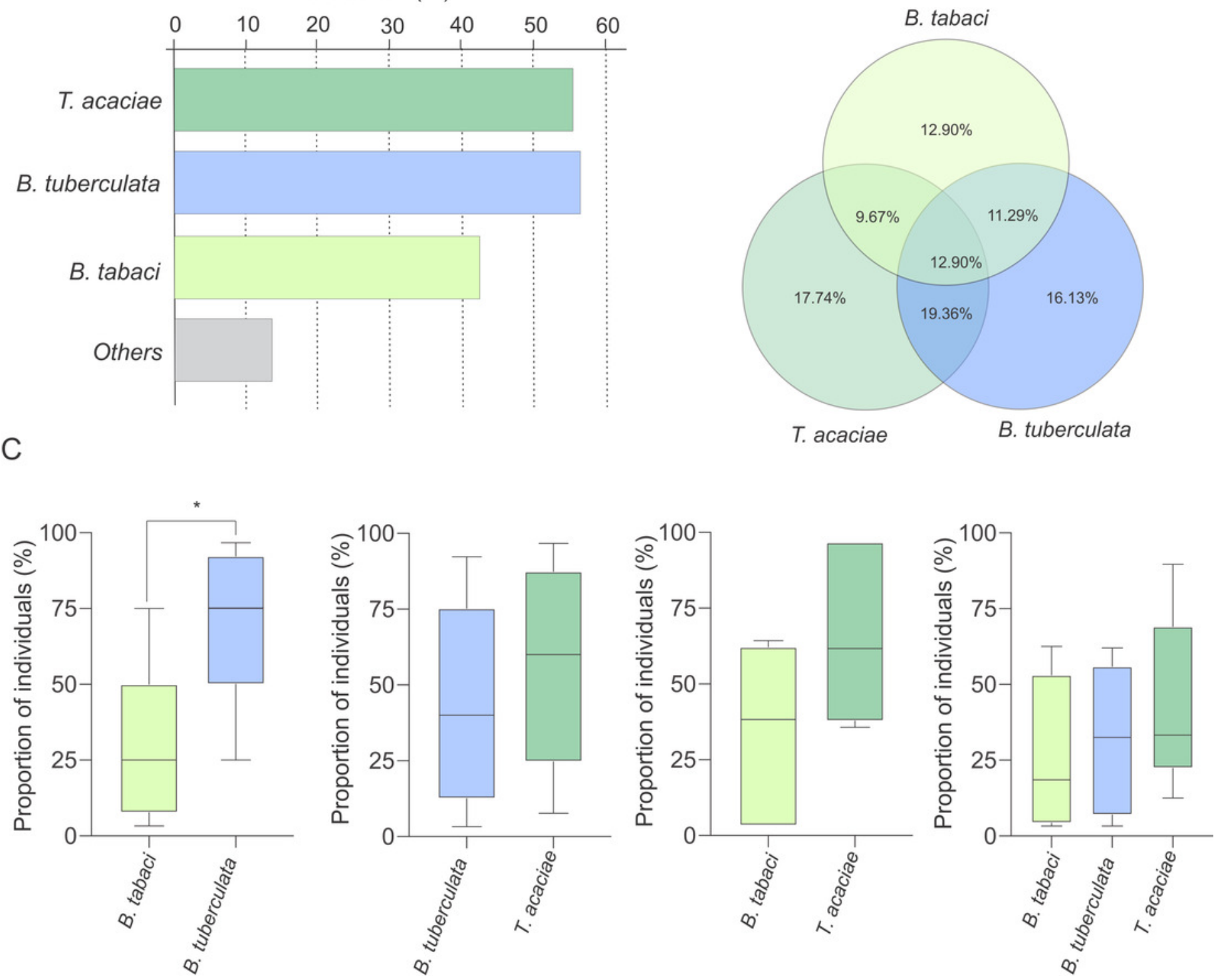


\section{Figure 5}

Composition and species diversity of whitefly populations differ among Brazilian regions

Figure 5. Composition and species diversity of whitefly populations differ among Brazilian regions. (A) Pie charts represent the distribution of the 1,385 individuals genotyped in this study in the five geographic regions of Brazil. (B) Boxplots correspond to Simpson's index of diversity (1-D) calculated for each geographic region. The index was first calculated for each sampled site and grouped by geographic region. Different letters indicate significant differences between groups according to the non-parametric Kruskal-Wallis test followed by post hoc multiple comparison test $(p<0.05)$.

A

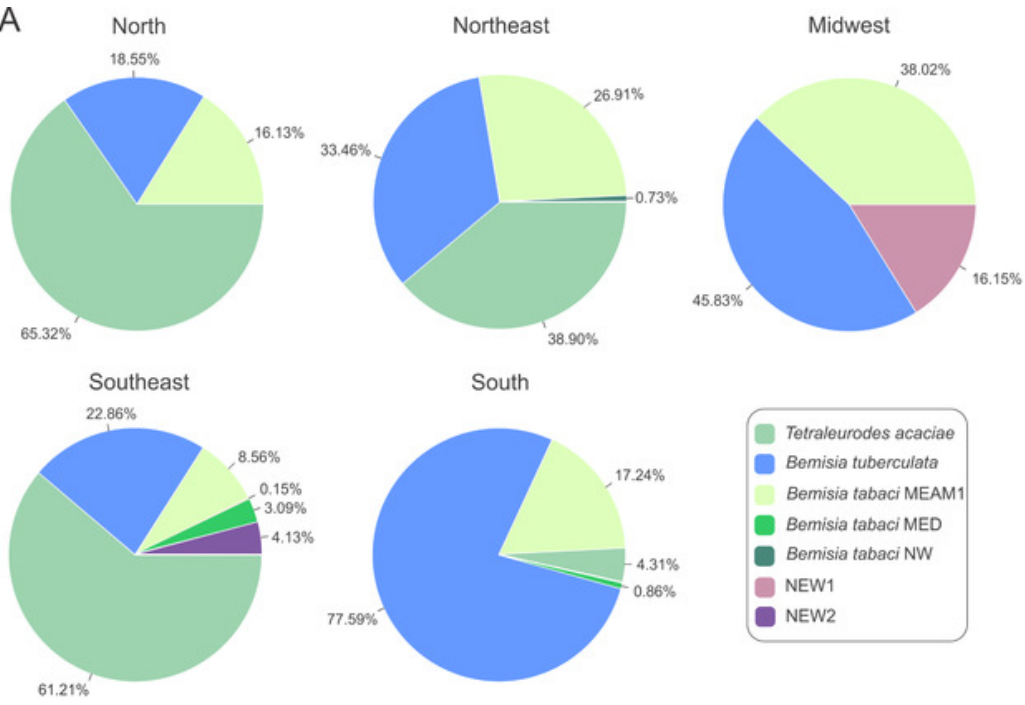

B

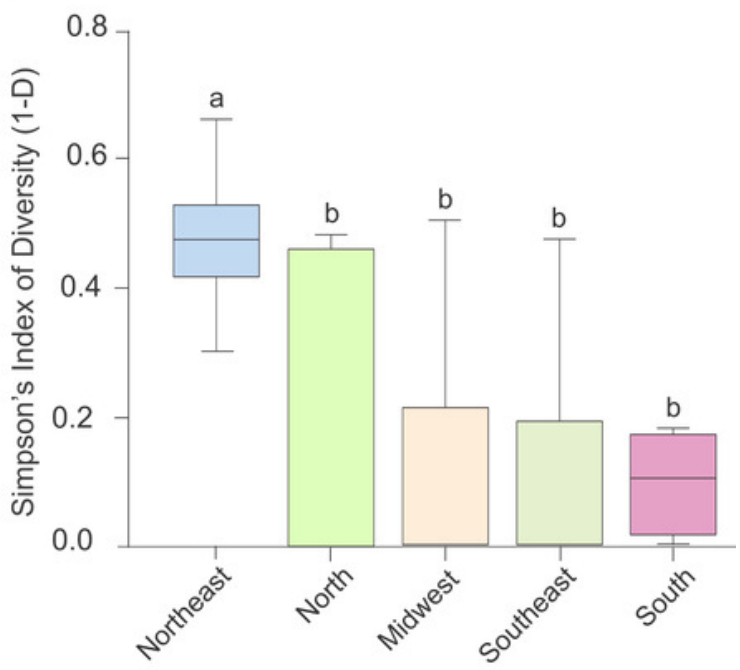

Macroregion 